\title{
Cyclopoid and calanoid copepod biodiversity in Indonesia
}

\author{
Victor R. ALEKSEEV,${ }^{1 *}$ Douglas G. HAFFNER, ${ }^{2}$ James J. VAILLANT, ${ }^{2}$ Fatimah M. YUSOFF ${ }^{3}$ \\ ${ }^{1}$ Zoological Institute, Russian Academy of Sciences, Universitetskaya Emb. 1, 199034 St. Petersburg, Russia; ${ }^{2}$ Great Lakes Institute \\ for Environmental Research, University of Windsor, 401 Sunset Avenue, ON N9B 3P4 Windsor, Ontario, Canada; ${ }^{3}$ Institute of Bio- \\ sciences, Putra Malaysian University, 43400 UPM-Serdang, Selangor, Malaysia \\ *Corresponding author: valekseev@yahoo.com
}

\begin{abstract}
Recent limnological investigations conducted on the large lakes of Indonesia provide valuable physical and ecological data for future environmental and developmental programmes, yet few studies have focused on zooplankton taxonomy. Here we describe Eucyclops troposperatus Alekseev et Yusoff n. sp. from a pond in Sumatra, and Mesocyclops jakartensis Alekseev n. sp. from a city pond in Jakarta, Java. In the pelagic zone of the lakes of Sulawesi we found only few copepod species. For the endemic cyclopoid Tropocyclops matanoensis Defaye, 2007, we propose a new subgenus, Defayeicyclops $n$. subg., and provide more data on the morphology as well as scanning electron microscopy and confocal laser scanning images of Tropocyclops (Defayeicyclops) matanoensis. Two other cyclopoid species were possibly introduced to Sulawesi: Mesocyclops aequatorialis similis Van de Velde, 1984 from Africa and Thermocyclops crassus (Fischer, 1853) from Eurasia. A new subspecies, Phyllodiaptomus praedictus sulawesensis Alekseev et Vaillant n. ssp. (Calanoida, Diaptomidae), is described from the plankton of lake Tondano, North Sulawesi, Indonesia. The new subspecies resembles P. blanci (de Guerne et Richard, 1896) and P. wellekensae Dumont et Reddy, 1992. Phyllodiaptomus praedictus sulawesensis appears to be endemic to Sulawesi island. The form matanensis formerly treated as a subspecies of Eodiaptomus wolterecki Brehm, 1933 is here elevated to species rank, E. matanensis Brehm, 1933. A preliminary list of the copepod species found in Sulawesi and other large islands of Indonesia now includes more than 60 species. An updated key to the Southeast Asian species of the genus Eucyclops is provided.
\end{abstract}

Key words: Copepoda, new species, subgenus Defayeicyclops, Indonesia.

Received: February 2013. Accepted: October 2013.

\section{INTRODUCTION}

Studies on the continental copepods of Southeast (SE) Asia started with the biological expeditions and private voyages of the western scientists to the SE Asia colonies in the $19^{\text {th }}$ and $20^{\text {th }}$ centuries. The first freshwater crustaceans (mainly ostracods) were collected by Max Weber and his wife during their travels in Sumatra, Java, Celebes (Sulawesi), and Flores in 1888. Several new ostracod species were described by Moniez (1892), based on their collection. Zooplankton and littoral sediment samples collected by Maryan Raciborski during his stay in Java in 1889-1900, were later studied by Grochmalicki (1915), who described two calanoid species from Java, Sulawesi and Bali. Menzel (1926), who lived in Java for two years, described 3 freshwater species of Bryocyclops (Tab. 1).

Major progress toward better understanding of the tropical copepod biodiversity has been the result of the German Sunda Expedition led by August Thienemann in 1928-1929, which investigated the inland waters of Java, Sumatra, and Bali. Based on Thienemann's materials, F. Kiefer described more than 15 copepods from Indonesia, primarily cyclopoids (Tab. 1). Kiefer's Reference Collection in Karslruhe (Germany) containing more than 11,000 slides and about 8000 wet samples has become one of the most important collections for the students of tropical copepod taxonomy (Franke, 1989).

The material collected by Richard Woltereck during the Wallacea Expedition to Celebes (now Sulawesi), Flores, Bali, and Java in 1932 was studied by Brehm (1933) who described several species and subspecies of the genus Eodiaptomus (Tab. 2).

Two other large important collections of the tropical copepods from this region should also be mentioned. Prof. Henri Dumont in Ghent established a rich tropical zooplankton collection on the basis of the material collected by the students of his Biodiversity course, organised in Belgium. Prof. Herbert Fernando (Waterloo, Canada) collected more than 14,000 samples himself from 78 countries, including Indonesia. This may be the largest private zooplankton collection which was donated and settled down in the Raffles Museum at Singapore University (Fernando and Alekseev, 1999).

Many scientists who also dealt with SE Asia copepods described altogether more than 40 species from this region (Tabs. 1 and 2). These descriptions are dispersed in the literature and have never been summarised, and most endemic species from Indonesia were found only once when first de- 
Tab. 1. Cyclopoid biodiversity in Indonesia.

\begin{tabular}{|c|c|c|c|}
\hline No. & Subfamilies, species & Islands & References \\
\hline & Halicyclopinae & & \\
\hline \multirow[t]{2}{*}{1} & Halicyclops thermophilus Kiefer, 1928 & Java & Kiefer (1928) \\
\hline & Eucyclopinae & & \\
\hline 2 & Afrocyclops gibsoni abbreviatus (Kiefer,1933) & Bali, Java & Kiefer (1933) \\
\hline 3 & Ectocyclops rubescens Brady, 1904* & Java & Kiefer's reference collection slide N 01697 \\
\hline 4 & Eucyclops agiloides (G.O. Sars, 1909) & Indonesia & Green et al. (1976) \\
\hline 5 & E. euacanthus (G.O. Sars, 1909) & Sumatra, lake Toba & Kiefer (1933) \\
\hline 6 & E. permixtus Kiefer, 1928 & Java & Kiefer (1929) \\
\hline 7 & E. ruttneri Kiefer, 1933 & Sumatra & Kiefer (1933) \\
\hline 8 & E. thienemanni Kiefer, 1930 & Java & Kiefer (1930b) \\
\hline 9 & E. troposperatus n. sp. ${ }^{*}$ & Sumatra & This paper \\
\hline 10 & Macrocyclops albidus (Jurine, 1820) & Java & Kiefer (1928) \\
\hline 11 & M. a. oligolasius Kiefer, 1928 & Sumatra & Kiefer (1933) \\
\hline 12 & M. neuter Kiefer, 1931 & Java & Heberer and Kiefer (1932) \\
\hline 13 & Paracyclops affinis (G.O. Sars, 1863) & Indonesia & Karaytug (1999) \\
\hline 14 & P. eucyclopoides Kiefer, 1929 & Bali, Java, Sumatra & Heberer and Kiefer (1932); Karaytug (1999) \\
\hline 15 & Thaumasiocyclops insulanus Kiefer, 1930 & Bali & Kiefer (1930b) \\
\hline 16 & Tropocyclops prasinus guwana Kiefer, 1931 & Java & Kiefer (1931) \\
\hline 17 & T. p. pelagica Lindberg, 1955 & Sumatra & Lindberg (1955) \\
\hline \multirow[t]{2}{*}{18} & T. (Defayeicyclops) matanoensis Defaye, $2009^{*}$ & Sulawesi, & Defaye (2009); this paper \\
\hline & Cyclopinae & . & \\
\hline 19 & Bryocyclops anninae (Menzel, 1926) & Java & Menzel (1926) \\
\hline 20 & B. chappuisi Kiefer, 1928 & Java & Kiefer (1928) \\
\hline 21 & B. bogoriensis (Menzel, 1926) & Java & Menzel (1926) \\
\hline 22 & B. muscicola (Menzel, 1926) & Java, Sumatra & Menzel (1926) \\
\hline 23 & Haplocyclops parvulus (Kiefer, 1928) & Java & Kiefer (1928) \\
\hline 24 & Megacyclops viridis acutulus Kiefer, 1930 & Java & Kiefer (1930) \\
\hline 25 & Microcyclops varicans subaeqalis (Kiefer, 1928) & Indonesia & Kiefer (1928) \\
\hline 26 & Microcyclops rubellus (Lilljeborg, 1901) & Java, Sumatra & Kiefer (1931) \\
\hline 27 & M. minimus (Kiefer, 1930) & Sumatra & Kiefer (1930a) \\
\hline 28 & M. sumatranus (Kiefer, 1930) & Sumatra & Kiefer (1930b) \\
\hline 29 & Mesocyclops aspericornis (Daday, 1906) & Java, Sulawesi, Kalimantan, Sumatra & $\begin{array}{l}\text { Kiefer (1929); } \\
\text { Hołyńska (2000) }\end{array}$ \\
\hline 30 & M. aequatorialis similis Van de Velde, $1984^{*}$ & Sulawesi & This paper \\
\hline 31 & M. thermocyclopoides Harada, 1931 & Java Flores & Hołyńska (2000) \\
\hline 32 & M. tobae Kiefer, 1933 & Sumatra & Kiefer (1933) \\
\hline 33 & M. papuensis Van de Velde, 1987 & Java, Kalimantan & Hołyńska (2000) \\
\hline 34 & M. affinis Van de Velde, 1987 & Indonesia & Hołyńska (2000) \\
\hline 35 & M. brevisetosus Dussart et Sarnita, 1987 & Kalimantan & Dussart and Sarnita (1987) \\
\hline 36 & M. pseudospinosus Dussart et Fernando, 1988 & Java & Dussart and Fernando (1988) \\
\hline 37 & M. dayakorum Holynska, 2000 & Kalimantan & Hołyńska (2000) \\
\hline 38 & M. francisci Holynska, 2000 & Sumatra & Hołyńska (2000) \\
\hline 39 & M. friendorum Holynska, 2000 & Sulawesi & Hołyńska (2000) \\
\hline 40 & M. geminus Holynska, 2000 & Kalimantan & Hołyńska (2000) \\
\hline 41 & M. jakartensis n. sp.* & Java & This paper \\
\hline 42 & Thermocyclops crassus (Fischer, 1853) & Java, Sumatra, Sulawesi & Kiefer (1933) \\
\hline 43 & T. c. microlasius Kiefer, 1952 & Sulawesi & Kiefer (1952) \\
\hline 44 & T. decipiens (Kiefer, 1929) & Indonesia & Kiefer (1933) \\
\hline 45 & T. operculifer (Kiefer, 1930) & Kalimantan, Java, Sulawesi, Lombok & $\begin{array}{c}\text { Heberer and Kiefer (1932); } \\
\text { Holynska (2006a) }\end{array}$ \\
\hline
\end{tabular}

"Taxa new to science or new records for Indonesia. 
scribed. Even though the total list for Indonesia obtained from literature analyses counts of about 60 cyclopoid and calanoid species, it is certainly incomplete, especially considering the transitional nature of the Malay archipelago.

The island of Sulawesi is part of a biogeographical transition zone known as Wallacea, which means that it homes a mixture of the Asian and Australasian species (Whitten et al., 2002). Significant endemism in the freshwater organisms has been just recently documented in mollusks, freshwater decapods and fishes. The first limnological studies in Sulawesi (then known as Celebes) were conducted in the $19^{\text {th }}$ century and were aimed to investigate the mollusk fauna (Sarasin and Sarasin, 1898).

The expedition of Woltereck, who visited Celebes in 1931, brought the first zooplankton and littoral microcrustaceans from this area to European scientists. After the analyses of these samples, Brehm (1933) described several endemic diaptomids including Neodiaptomus lymphatus Brehm, 1933, Eodiaptomus wolterecki matanaensis Brehm, 1933, E. wolterecki celebensis Brehm, 1933, and E. wolterecki tominangae Brehm, 1942.
Only 70 years after Brehm's pioneer study, two more endemic copepods, Mesocyclops friendorum Hołyńska, 2000 from South Sulawesi and Tropocyclops matanoensis Defaye, 2007, from lake Matano were described.

Since 1990, several limnological investigations have been conducted to assess the status of the large lakes of Indonesia to provide data for future environmental and developmental programmes. However, few studies have focused on lake zooplankton. Although the lakes of Sulawesi are known to possess remarkably high levels of endemism, the copepod fauna of the island has remained very poorly investigated.

The goal of this study is to improve our understanding of the tropical copepod biodiversity in this area, combining the sporadic literature data with some of our own materials recently collected from the 4 largest islands of Indonesia (Java, Kalimantan, Sulawesi and Sumatra) using modern techniques including confocal laser scanning microscopy and molecular genetic analyses.

Of particular interest are the ancient Malili lakes in Sulawesi, which are characterised by unique physico-

Tab. 2. Calanoid biodiversity in Indonesia.

\begin{tabular}{|c|c|c|c|}
\hline No. & Family, species & Islands & References \\
\hline & Pseudodiaptomidae & & \\
\hline 1 & Pseudodiaptomus poppei Stingelin, 1900 & Sulawesi & Stingelin (1900) \\
\hline 2 & P. annandalei Sewell,1919 & Java & Brehm (1933) \\
\hline \multirow[t]{2}{*}{3} & P. dauglishi Sewell, 1932 & Sumatra & Kiefer (1939) \\
\hline & Acartidae & & \\
\hline 4 & Acartia erythraea valdiviae Steuer, 1923 & Sulawesi & Steuer (1923) \\
\hline \multirow[t]{2}{*}{5} & A. bispinosa Carl, 1907 & Indonesia, Maluku & Carl (1907) \\
\hline & Diaptomidae & & \\
\hline 6 & Dentodiaptomus javanus Grochmalicki, 1915 & Java & Grochmalicki (1915) \\
\hline 7 & Eodiaptomus wolterecki Brehm, 1933 & Sulawesi & Brehm (1933); this paper \\
\hline 8 & E. w. celebensis Brehm, 1942 & Sulawesi & Brehm (1942) \\
\hline 9 & E. w. tominangae Brehm, 1942 & Sulawesi & Brehm (1942) \\
\hline 10 & E. matanensis Brehm, 1933 & Sulawesi & Brehm (1933); this paper \\
\hline 11 & Heliodiaptomus kieferi Brehm et Chappuis, 1939 & Java & Brehm and Chappuis (1935) \\
\hline 12 & Mongolodiaptomus uenoi Kikuchi, 1936 & Java, Kalimantan & Kiefer (1938) \\
\hline 13 & M. mephistopheles (Brehm, 1933) & Java & Brehm (1933) \\
\hline 14 & Neodiaptomus lymphatus Brehm, 1933 & Sulawesi & Brehm (1933); this paper \\
\hline 15 & N. blanchei Brehm, 1951 & Java & Lai and Fernado (1980) \\
\hline 16 & Phyllodiaptomus praedictus sulawesensis Alekseev et Vaillant n. ssp. & Sulawesi & This paper \\
\hline 17 & Tropodiaptomus doriai (Richard, 1894) & Java, Sulawesi, Sumatra & $\begin{array}{c}\text { Richard (1894); Brehm (1930); } \\
\text { Lai (1986) }\end{array}$ \\
\hline 18 & T. malaicus Grochmalicki, 1915 & Java, Sulawesi & Grochmalicki (1915); Brehm (1934) \\
\hline 19 & T. vandouwei (Frühtl, 1924) & Indonesia & Kiefer (1982) \\
\hline 20 & T. hebereri Kiefer, 1930 & Java, Sumatra & Brehm (1930) \\
\hline 21 & T. vicinus (Kiefer, 1930) & Sumatra, Kalimantan & Lai (1986) \\
\hline 22 & T. australis Kiefer, 1936 & Java, Sumatra & Lai and Fernado (1980) \\
\hline
\end{tabular}

${ }^{*}$ Taxa new to science or new records for Indonesia. 
chemical conditions and long-term existence, and represent the only hydrologically connected system of ancient lakes in the world. As such, they have been the focus of many recent evolutionary studies. However, detailed taxonomic work is needed for the zooplankton of Wallacea in order to lay the foundation for further ecological and evolutionary investigations in these taxa. Here we describe Eucyclops troposperatus Alekseev et Yusoff n. sp. (Cyclopoida, Cyclopidae) from a pond in Sumatra. We erected a new subgenus Defayeicyclops and provided scanning electron microscopy (SEM) images of the type species of the subgenus, Tropocyclops (Defayeicyclops) matanoensis Defaye, 2007. Phyllodiaptomus praedictus sulawesensis Alekseev et Vaillant n. ssp. (Calanoida, Diaptomidae) is also described from lake Tondano (North Sulawesi). Furthermore, we briefly revise the descriptions and classification of several copepod taxa from the lakes of Sulawesi, and provide them with molecular-genetic identifications (barcodes) for future phylogenetic studies.

\section{METHODS}

For comparison and better delineation of the taxa we examined specimens from both museum collections and recent collectings.

\section{Zoological Institute Federal Collection (copepod division)}

Eucyclops speratus (Lilljeborg, 1901) 2 females and 1 male collected in lake in Ploen, North Germany, (V. Alekseev leg.) were used for comparison with a morphologically close, new species from Sumatra.

\section{F. Kiefer's Collection}

(Reference slides examined in the Karlsruhe Museum; labels were translated from German).

Phyllodiaptomus annae (Apstein, 1907): NN0193901940, Diaptomus annae, female, lake Colombo, Ceylon, 07.1905; N01941, Diaptomus annae, male, lake Colombo, Ceylon, 07.1905.

Ectocyclops rubescens Brady, 1904: N01697, Ectocyclops rubescens, male, Diengochflache, Java, Indonesia, 04.06,1929, leg. Thienemann.

Eodiaptomus wolterecki (Brehm, 1933): NN0402104022, 04024, Eodiaptomus wolterecki, lake Towuti, Celebes, Indonesia, leg. Woltereck.

Eodiaptomus matanensis (Brehm, 1933): NN 0418904190, Eodiaptomus matanensis, male + female, lake Towuti, Celebes, Indonesia, leg. Woltereck.

Mesocyclops aequatorialis similis Van de Velde, 1984 (Van de Velde, 1984): 04585, Mesocyclops leuckarti aequatorialis, 3 females, A1-P4, Manyas-Golu, Turkey, 18.07.1935, leg. Kosswig; 04586 Mesocyclops leuckarti aequatorialis, 3 females, Abd, Manyas-Golu, Turkey;
18.07.1935, leg. Kosswig; 04587 Mesocyclops leuckarti aequatorialis, 6 females, Abd, Apolyont-Golu, Bursa, Turkey; 07.1934, leg. Kosswig; 04588 Mesocyclops leuckarti aequatorialis?, 2 females, A1-P4, BeyshahirGolu, Turkey, 06.08.1941, leg. Kosswig; 04589, Mesocyclops leuckarti aequatorialis, 2 females, A1-P4, Manyas-Golu, Turkey, 18.07.1935, leg. Kosswig; 04724 Mesocyclops aequatorialis, female, A1-P4, lake Kivu, Congo, Plankton, 08.10.1935, leg. Damas; 04725 Mesocyclops aequatorialis, female, Abd., lake Kivu, Congo, Plankton, 08.10.1935, leg. Damas.

\section{Collecting in Java island}

Four samples were collected with a handle net by V.A. in city ponds of Jakarta on March 29-31, 2008, preserved in $85-90 \%$ ethanol and then studied with morphological methods.

\section{Collecting in Sumatra island}

Two samples were collected by F.Y. in a lake near Singkarat and in a small pond in Dumen town July 18-20, 2011, preserved in 4\% formalin and then studied with morphological methods.

\section{Collecting in Sulawesi island}

More intensive sampling was done in ancient Sulawesi lakes by J.V. and D.G.H. Five lakes in Sulawesi, Indonesia, including lakes Tondano and Poso, lakes Matano, Mahalona, and Towuti of the Malili lake system, and two lakes - Tolire and Laguna - of the neighbouring island Ternate have been surveyed (Fig. 1B). Samplings were done in the pelagic zone through $10 \mathrm{~m}$ vertical tows of a $62-\mu \mathrm{m}$-mesh large zooplankton net (1 m diameter). Specimens were immediately preserved in $95 \%$ ethanol.

All samples were sorted in the laboratory under a dissection microscope (Olympus SZX2; Olympus, Tokyo, Japan), and if possible 4-12 adults from each population were selected for analyses. Before dissection, adult copepods were photographed with a digital camera and measured with an ocular micrometer ( $5 \mu \mathrm{m}$ resolution). After dissection, the individuals were placed on slides in pure glycerol, covered with a cover slip and ringed with Canadian balsam. The slides were then observed and drawn at a maximum magnification of $1000 \times(10 \times$ ocular, $100 \mathrm{x}$ objective, oil immersion) under a compound microscope (Zeiss IMAGER; Zeiss, Oberkochen, Germany) equipped with Nomarski system for differential interference contrast microscopy and a drawing tube. Pencil drawings were converted to India ink and placed on A4 size tracing paper. The drawings were scanned and then edited by a computer programme (Adobe Photoshop). All body measurements were done on undissected animals gently fixed but not compressed in ventral position with a cover slide 
supported by small pieces of plasticin. To assess body asymmetry we used an index of asymmetry (Iass=right side/left side) that was applied to the genital somite, lateral spine of the somite and lateral wings of the last thoracic somite. For terminology, we mainly followed Huys and Boxshall (1991).
Molecular genetic identification in the four endemic/newly described diaptomids from Sulawesi was done using a partial nucleotide sequence of the c oxidase subunit I (COI) mitochondrial gene (511 bp) known as a DNA barcode. Voucher specimens of those species are deposited in the Federal Zoological Collection of Russian
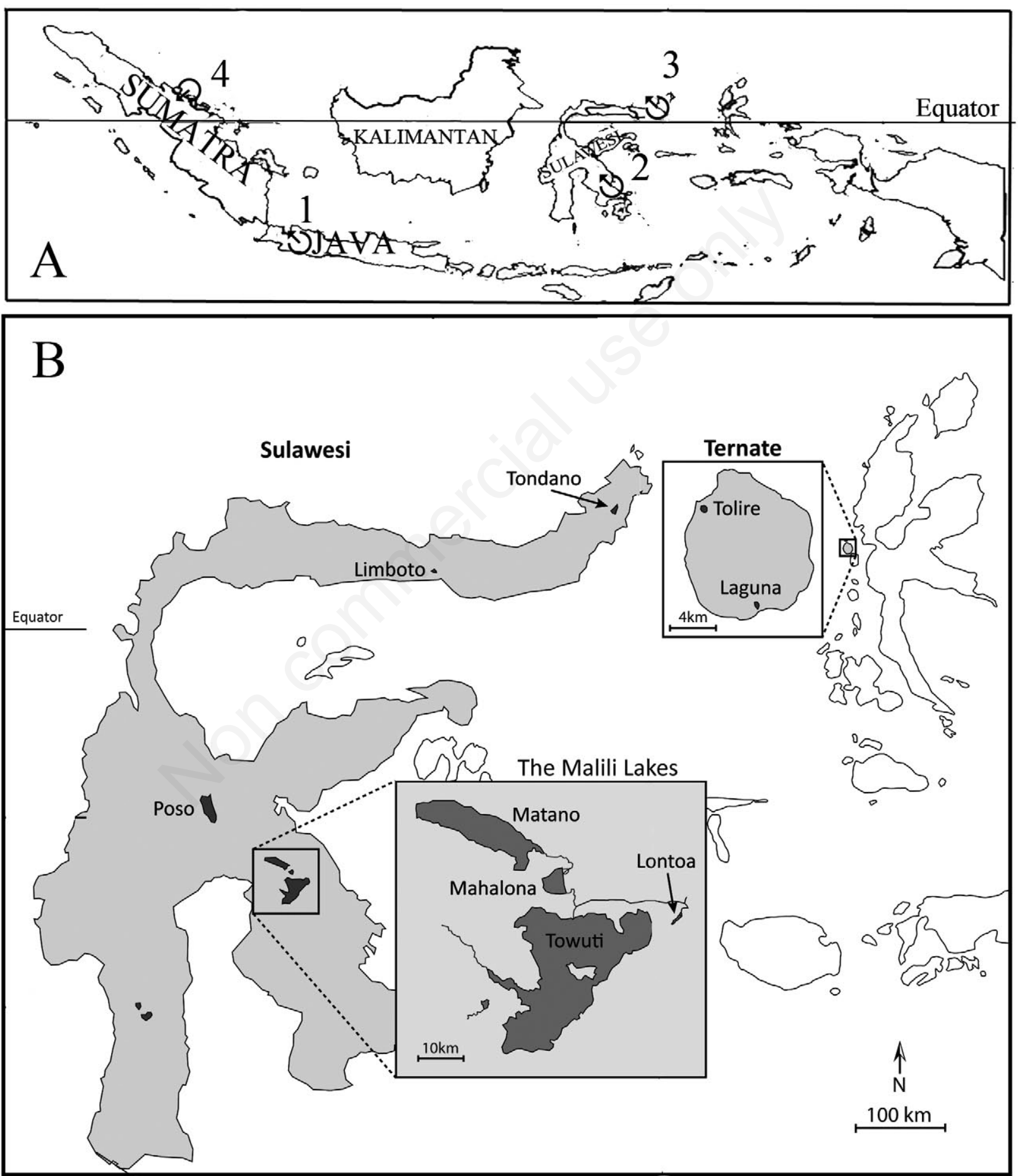

Fig. 1. Collecting sites in Indonesia (A), with lake locations across Sulawesi and Ternate (B). Numbers and arrow in circle indicate sampling sites. 
Academy of Sciences, Zoological Institute, St. Petersburg, Russia.

The crustaceans were fixed in $95 \%$ alcohol, and total genomic DNA was extracted from single individuals (adults or late copepodite stages) using a modified proteinase $K$ method (Schwenk et al., 1998). To amplify the gene, we used universal forward and reverse primers, respectively, HCO2198 (5'-TAA ACT TCA GGG TGA CCAAAAAAT CA-3') and LCO1490 (5'-GGT CAA CAAATC ATAAAG ATA TTG G-3') (Folmer et al., 1994). The profile of polymerase chain reaction (PCR) was the following: initial denaturing for $5 \mathrm{~min}$ at $94^{\circ} \mathrm{C}$; five cycles of $30 \mathrm{~s}$ at $90^{\circ} \mathrm{C}, 60 \mathrm{~s}$ at $45^{\circ} \mathrm{C}$, and $90 \mathrm{~s}$ at $72^{\circ} \mathrm{C}$; then, 27 cycles of $30 \mathrm{~s}$ at $90^{\circ} \mathrm{C}$, $45 \mathrm{~s}$ at $55^{\circ} \mathrm{C}$, and $60 \mathrm{~s}$ at $72^{\circ} \mathrm{C}$; and terminal elongation for 5 min at $72^{\circ} \mathrm{C}$. Following amplification, PCR products were purified using the solid phase reversible immobilisation (SPRI) method (De Angelis et al., 1995). Sequencing reactions were performed using forward primers and BigDye Terminator 3.1 chemistry on an ABI 3130XL automated sequencer (Applied Biosystems, Foster City, CA, USA). Sequences were aligned and quality controlled using CodonCode Aligner v.2.0.6 (CodonCode Corporation, Dedham, MA, USA). Maximum-likelihood phylogenetic reconstructions were performed in MEGA v. 4 (Tamura et al., 2007) using the $\operatorname{TrN}$ substitution model and $10^{3}$ bootstrap replicates. Mongolodiaptomus birulai from Taiwan (accession no. AB592995.1) was used as an outgroup.

\section{RESULTS}

Our findings from Java, Sumatra and Sulawesi are presented in island-wise order. In the few samples that we had from Java and Sumatra islands we only found cyclopoid copepods, while in Sulawesi we collected both Cyclopoida and Calanoida.

\section{Java: Cyclopoida}

Only two samples (st.2 and st.4) from Jakarta (Java) contained adult copepods, and those are: Microcyclops varicans (G.O. Sars, 1863), Microcyclops sp., Mesocyclops thermocyclopoides Harada, 1931, and Mesocyclops cf. affinis. The latter taxon was presented by a pitted form (pits were most conspicuous on the distal segments of the antennule and antenna) that is hereafter described as a new species.

\section{Family Cyclopidae Rafinesque, 1815}

\section{Subfamily Cyclopinae Rafinesque, 1815}

\section{Genus Mesocyclops G.O. Sars, 1914}

Mesocyclops jakartensis Alekseev n. sp. (Figs. 2-4)

\section{Systematics}

Type material: holotype, ZIN RN 55067, female dis- sected on 1 slide; Gold Sily pond in Jakarta, Java, Indonesia, collected by Victor Alekseev, March 30, 2008 (GPS coordinates: 6 07'037'S; 10647'643"E). Paratype, ZIN RN 55068 a male dissected on one slide, from the same locality as the holotype; other paratypes, ZIN RN 55069ac: 2 dissected male and 4 undissected female, from the same locality as the holotype.

Etymology: the species is named after the type locality, Jakarta, capital of Indonesia.

Female (holotype): length: $1080 \mu \mathrm{m}$, without caudal setae and $1663 \mu \mathrm{m}$ if caudal setae included. Body slender and transparent without colour (Fig. 3A). Cephalothorax 1.1 times as long as wide, with maximum width close to posterior margin. Pediger 5 with a group of long rare hairsetae on lateral margin. Genital double-somite as long as wide, without hair-setae, lateral arms of seminal receptacle short and wide, with horseshoe-shaped copulatory pore. Transverse ducts not V-shaped, copulatory duct wide and straight (Fig. 2H). Caudal rami 2.3-2.5 times as long as wide, without hair-setae on medial margin, ending in six setae (Fig. 2I). Length of four terminal setae, from outermost to innermost seta: $83 / 340 / 443 / 247 \mu \mathrm{m}$. Dorsal seta 0.69 times as long as outermost terminal seta (0.8-1.2 in $M$. affinis) and lateral seta about half length of outermost seta; at base of this seta, 5 strong denticles inserted dorsally, spinules absent at implantation of lateral caudal seta (Fig. 2I). Innermost seta ornamented with dense setules on both sides. Longest terminal seta 1.23 times as long as urosome, outermost seta as long as caudal rami.

Antennule 17-segmented, reaching the posterior margin of second free somite, with serrated hyaline membrane with one large notch on last segment (Fig. 3B) Armature formula of antennule from segment 1 to 17 as follows (Arabic numerals denote setae): 8, 4, 2, 6, 4, 2, 2 , $1,1,0,1$, aesthetasc (ae)+1, 0, 1, 2, ae+2, ae+7. Surface of antennule and antenna with dense small pits (Fig. 2C).

Antenna 4-segmented, composed of basipodite (BAS) and 3-segmented endopodite (ENP) with 3 setae on BAS and 1, 7, 7 setae on first to third segment of ENP, respectively (Fig. 3G). Caudal spinule ornamentation of BAS (Fig. 2A) composed of longitudinal row (25-27 spinules) along lateral margin and 1-2 spinules (arrowed) next to insertion of exopodite (EXP) seta; 5-7 long spinules proximally next lateral margin, and row of spinules of different size along proximal margin closer medial margin. Frontal spinule pattern of antennal BAS consisting of long proximal row of large spinules (18-20 spinules); 3 spinules next to insertion of EXP seta; wide field of long spinules close to insertion of medial setae (arrowed) and two rows of tiny spinules below the field (Fig. 2B). Spinule ornamentation resembling that in M. affinis, differences are as follows: on caudal side with one strong spine near insertion of EXP (Fig. 2A, arrowed); on frontal side field of relatively long spinules (instead of tiny spinules in $M$. affi- 
nis) next to insertion of medial setae (Fig. 2B, arrowed), longitudinal lateral row consisting of 18-20 spinules (716 in M. affinis).

Mandible (Fig. 3C): gnathobase ending with 9 teeth and 1 denticulate seta; palp (ENP) with 2 long setae cov- ered with long hair-like setules and short hairless seta. Maxillule consisting of praecoxa (not shown) armed with 6 setae and 5 spines, and 2-segmented maxillulary palp (Fig. 3F) with 7 setae, palp without ornamentation. Maxilla (Fig. 3D) syncoxopodite partly divided into praecox-

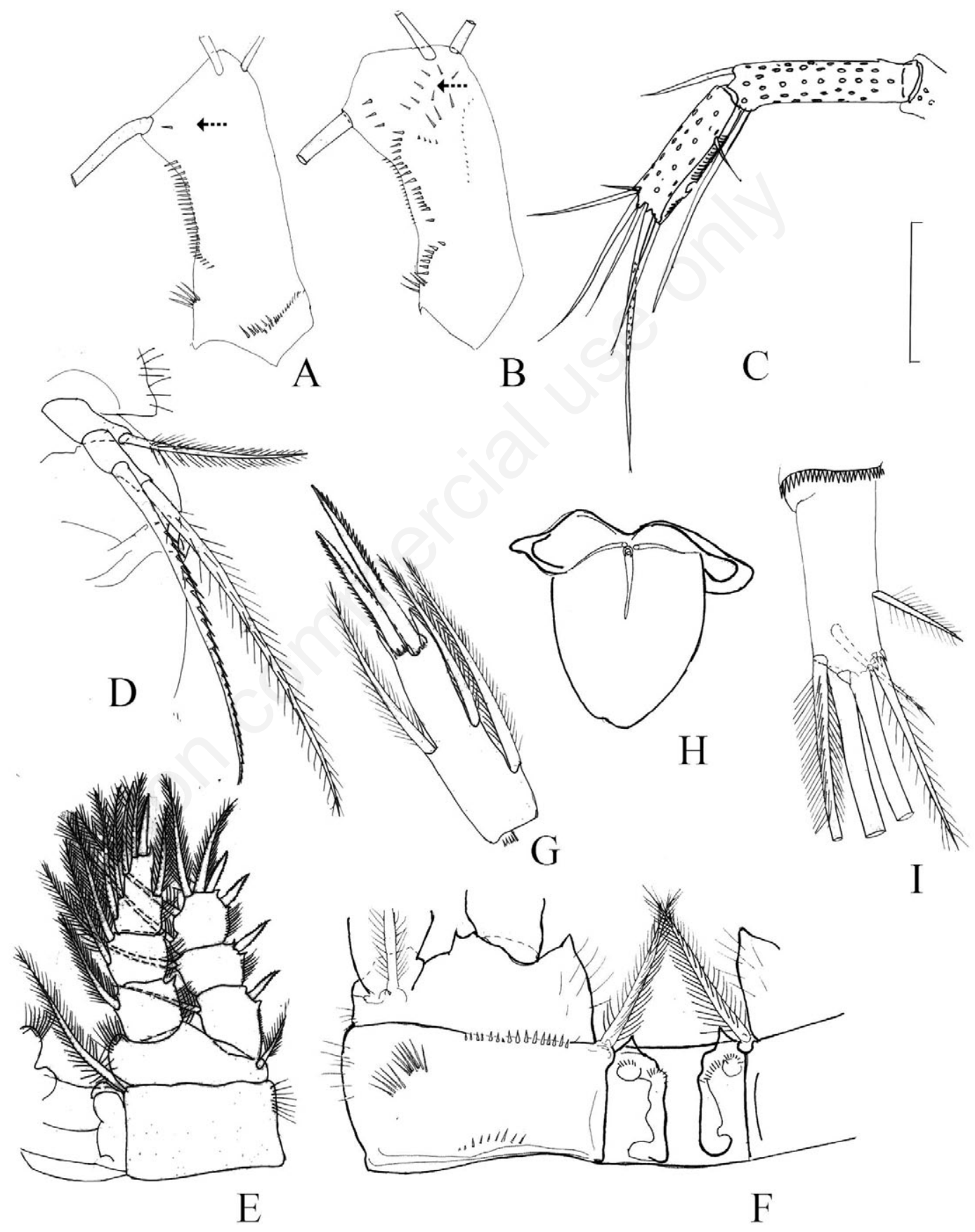

Fig. 2. Mesocyclops jakartensis n. sp., pond in Jakarta, Java, female holotype. A, B) Basipodite of antenna, caudal and frontal sides (arrows indicate spinule next to exopodal seta on caudal surface, and long spinules near insertion of medial setae on frontal surface); C) distal segments of antennule; D) rudimentary leg 5; E) leg 1; F) coxopodite and basipodite of leg 4, caudal side; G) distal segment of $\mathrm{P} 4$ endopodite; H) receptaculum seminis; I) caudal ramus, ventral side. Scale bars of A,B,D,G,I,F) $=35 \mu \mathrm{m} ; \mathrm{C}, \mathrm{E})=50 \mu \mathrm{m}$. 
opodite with one endite (bearing 2 strong setae) and coxopodite with 2 endites, more proximal endite bearing one seta, and distal endite bearing 1 thin and 1 strong seta. Frontal surface of coxopodite with several rows of long hair-like setules [in M. affinis with field of short spinules, after Hołyńska (2000)]. Basipodite with claw-like endite armed with long lateral row of denticles and 2 setae. Onesegmented ENP with 5 setae of different length. Maxilliped (Fig. 3E) with 4 segments, syncoxopodite with 3 strong setae; BAS with 2 setae of different length, caudally with spinules arranged in 2 groups near lateral margin, and long spinules on medial and frontal surface; first segment of ENP with strong seta and distal segment with 1 strong and 2 short setae.

Swimming legs 1-4 (P1-P4) with 3-segmented rami (Fig. 2E). Spine formula of EXP3 of P1-P4: 2-3-3-3. P1 BAS without medial spine (Fig. 2E). P4 coxopodite with groups of spines and hair-setae similar to those in M. affinis. Coxal spine of $\mathrm{P} 4$ strong and long, with homonomous setulation. Intercoxal plate of $\mathrm{P} 4$ with 2 acute, as long as wide, prominences and 2 small symmetrical groups of short hair-setae on caudal surface (missing in M. affinis). Basipodite with long sparse hair-like setules on inner margin (Fig. 2F). P4 ENP3 elongated, 2.78 times as long as

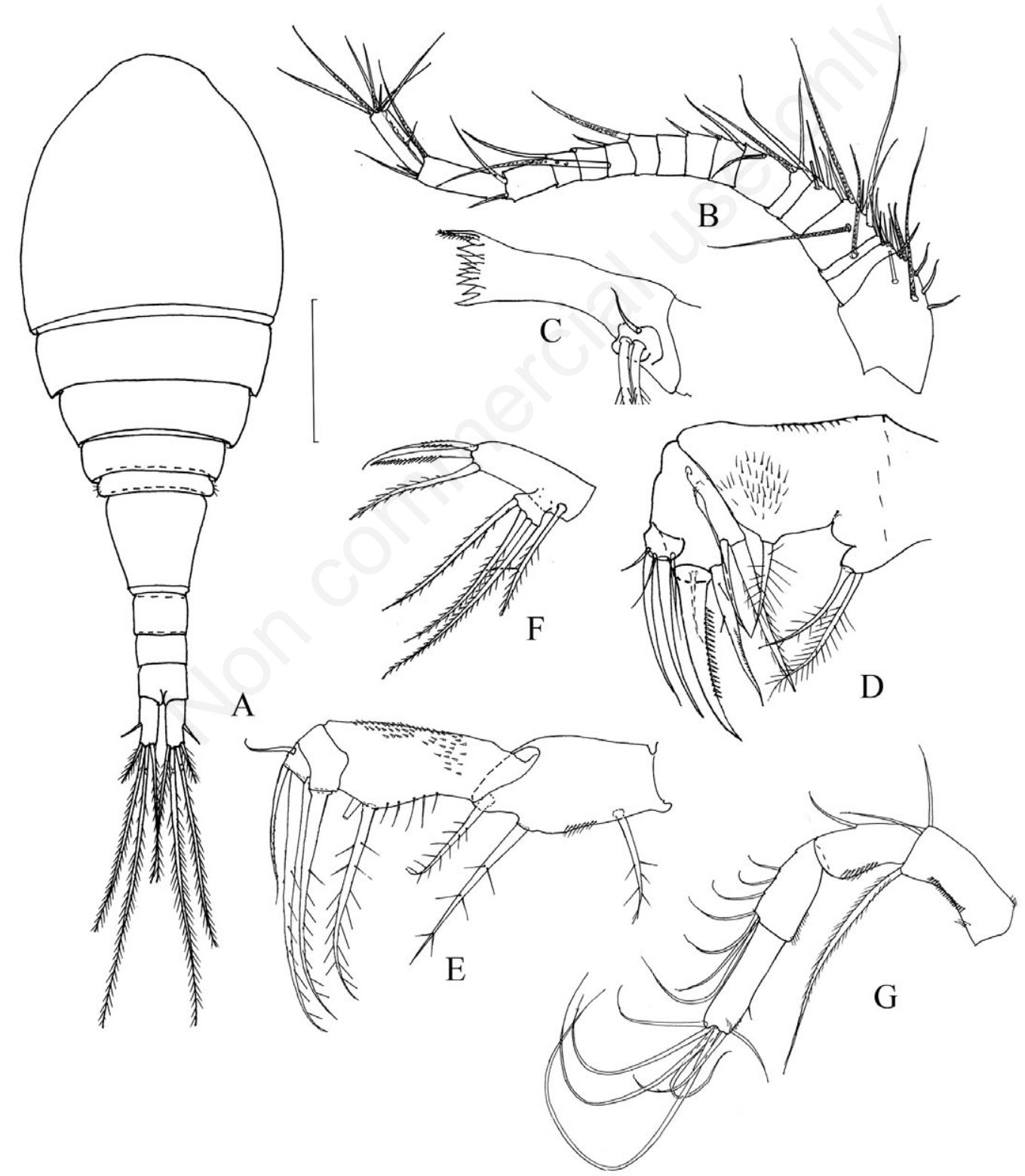

Fig. 3. Mesocyclops jakartensis n. sp., pond in Jakarta, Java, female holotype. A) Habitus, dorsal; B) antennule; C) mandible; D) maxilla; E) maxilliped; F) maxillulary palp; G) antenna. Scale bars of A) $=225 \mu \mathrm{m}$; B) $=75 \mu \mathrm{m} ; \mathrm{D}, \mathrm{E})=50 \mu \mathrm{m} ; \mathrm{C}, \mathrm{F})=25 \mu \mathrm{m}$. 
wide, with 2 strong apical spines, inner spine 1.2-1.35 times as long as outer spine, and as long as segment itself (Fig. 2G). Distal setae of P4 ENP3 not reaching distal ends of nearest spines.

Leg 5 (Fig. 2D) 2-segmented, with strong inner spine, apical seta 1.1 times as long as medial spine (1.1-1.6 in M. affinis), lateral seta 0.54 times as long as medial spine.

Male (paratypes): significantly smaller than female, length without caudal setae $656-670 \mu \mathrm{m}$, with caudal setae 1040-1050 $\mu \mathrm{m}$. Pediger 5 without hair-setae on lateral margin (Fig. 4A). Caudal rami 2.6 times as long as wide, smooth, with few spinules at implantations of lateral and outermost setae. Length of terminal caudal setae, from outermost to innermost setae: 56/213/275/150 $\mu \mathrm{m}$. Dorsal seta $38 \mu \mathrm{m}$, and 0.67 times as long as outermost terminal seta. Lateral seta 0.37 times as long as outermost terminal seta. P4 coxopodite basically as in female (Fig. 4E). Intercoxal plate of P4 with 2 acute outgrowths but shorter than in female, and with 2 small symmetrical groups of short hair-setae on the caudal surface, with few setules in each group. Coxal spine long but more slender than in female (Fig. 4E). P4 ENP3 clearly bent in outer margin, 2.57 times as long as wide, with 2 strong and slightly bent apical spines; inner spine 1.23 times as long
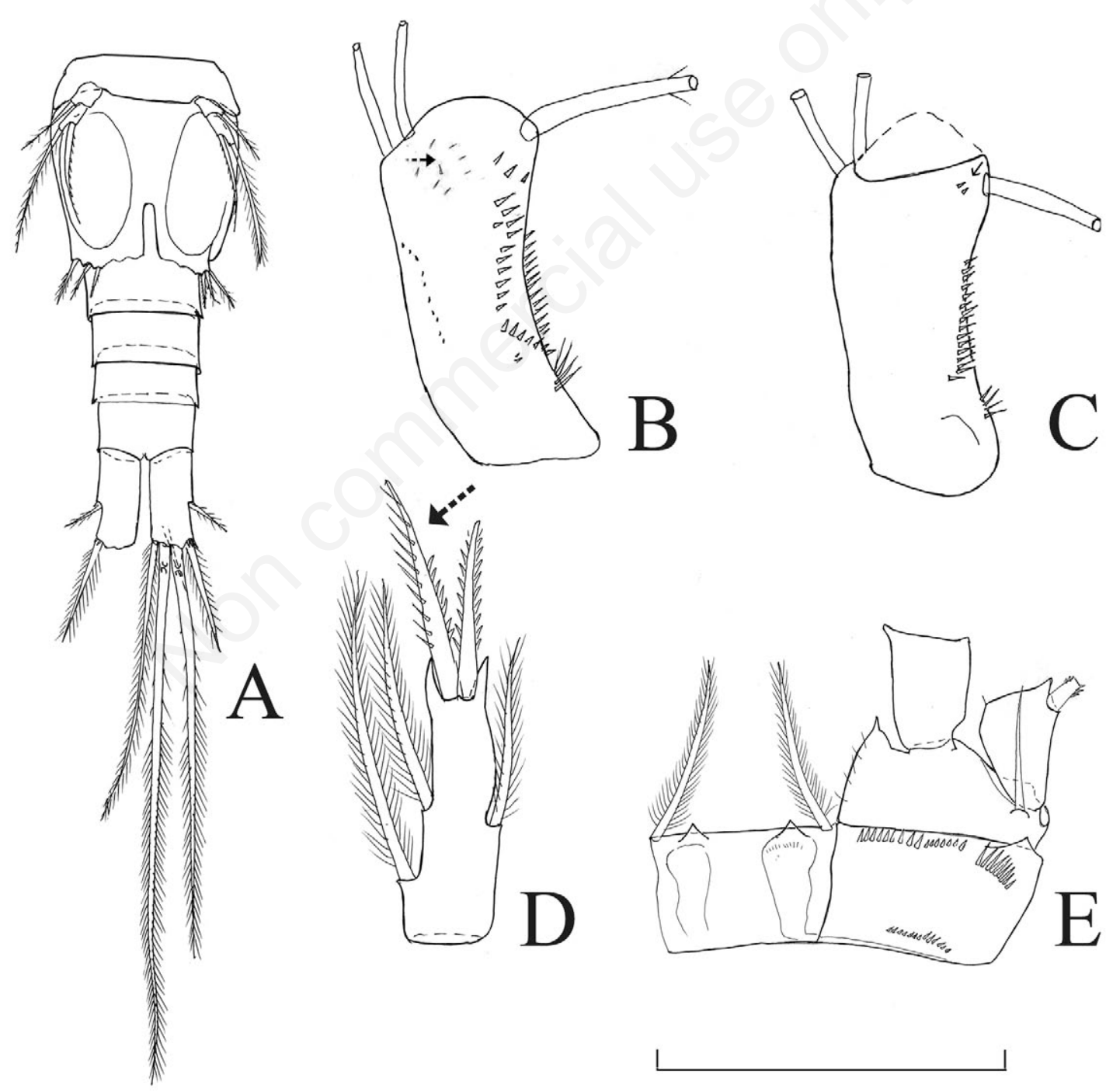

Fig. 4. Mesocyclops jakartensis n. sp., pond in Jakarta, Java, male paratype. A) Urosome, ventral; B,C) basipodite of antenna, frontal and caudal sides [arrows indicate spinule group near insertion of medial setae on frontal (B) and few spinules next to exopodite seta on caudal (C) sides]; D) distal segment of P4 endopodite (arrow indicates lack of spinules in apical part of inner terminal spine); E) coxopodite and basipodite of leg 4 , caudal side. Scale bars of A) $=200 \mu \mathrm{m} ; \mathrm{B}-\mathrm{E})=50 \mu \mathrm{m}$. 
as outer spine and shorter than segment itself (Fig. 4D). Outer edge of inner spine partly without denticles (Fig. 4D, arrowed). Leg 5 with strong inner spine 0.77 times as long as apical seta; lateral seta about half of apical seta (Fig. 4A).

Geniculate antennule and antenna with dense small pits similar to female (not shown). Basipodite of A2: caudal spinule ornamentation composed of longitudinal row (20-22 spinules) along lateral margin and 2 spinules next to insertion of EXP seta (Fig. 4C, arrowed); 4-5 long spinules proximally near lateral margin and row of spinules of different size along proximal margin. Frontal spinule pattern of antennary BAS consisting of long longitudinal row of large spinules (14-16 spinules); 3 spinules next to insertion of EXP seta; field of long spinules close to insertion of medial setae and row of tiny spinules as in female (Fig. 4B, arrowed).

\section{Comments}

M. jakartensis n. sp. is very close to M. affinis described by Van de Velde (1987) from Papua New Guinea and later on found by Hołyńska $(2000,2006 \mathrm{~b})$ in Malaysia, Thailand and in Indonesia (Java, Sumatra, Bali, Borneo, Sulawesi and Lombok). In the guide to the Mesocyclops genus (Hołyńska et al., 2003), as well as in a revision of the Australasian Mesocyclops species, (Hołyńska, 2000) the description of this species included quite a wide range of the variation in taxonomically important features, only partly overlapping those in $M$. jakartensis n. sp. (Tab. 3). Presence of short hair-like setules on P4 intercoxal plate (both in male and female) in M. jakartensis n. sp. (smooth plate in M. affinis) clearly separates the two species. These two species also differ in the caudal rami proportion, relative length of the dorsal caudal seta and P4 ENP3 distal spine ratio (Tab. 3).

Additionally, there are several other differences between the two taxa in the microcharacters of the mouth appendages. In M. jakartensis n. sp. a group of large spinules (Fig. 2B, arrowed) is present on the frontal side of antennal BAS. In $M$. affinis this group is presented by tiny spinules (Hołyńska, 2000). The longitudinal lateral row on the frontal side of the antennal BAS consists of 18-20 spinules in M. jakartensis n. sp. (7-16 in M. affinis). The second segment of the maxilla is with a group of small spinules on frontal side in M. affinis (Hołyńska, 2000), while the corresponding segment is with long hair-like spinules in M. jakartensis n. sp. (Fig. 3D).

M. jakartensis n. sp. appears to inhabit ephemeral water bodies, indicated by the presence of pits on their body and appendages. A similar morphological transformation can be found in other cylopid species with similar ecology, for example in Cyclops singularis Einsle, 1996.

\section{Ecology and distribution}

This species seems to inhabit small waterbodies that are periodically dried up, or temporarily wet parts of the larger waters. Adaptations to temporary habitats (vs to permanent waterbodies in $M$. affinis) with a kind of dormancy in the life cycle of $M$. jakartensis n. sp. (strongly necessary in ephemeral waters yet useless in permanent waterbodies in the tropics) could be an explanation for the supposedly sympatric (but ecologically separate) occurrence of these species in Indonesia.

\section{Sumatra: Cyclopoida}

Samples from a small city pond in Sumatra island contained 3 cyclopoid copepods: Microcyclops rubellus (Lilljeborg, 1901), Mesocyclops thermocyclopodes Harada, 1931, and Eucyclops sp., herein described as new species for science.

\section{Family Cyclopidae Rafinesque, 1815}

Subfamily Eucyclopinae Kiefer, 1927

\section{Genus Eucyclops Claus, 1893}

Eucyclops troposperatus Alekseev et Yusoff n. sp. (Fig. 5)

\section{Systematics}

Type material: holotype, ZIN RN 55070, a female dissected on 1 slide; city pond in Dumen, Sumatra, Indone-

Tab. 3. Some morphological features in Mesocyclops jakartensis n. sp. and Mesocyclops affinis Van de Velde, 1987.

\begin{tabular}{lcc}
\hline Features in females & Mesocyclops jakartensis n. sp. & Mesocyclops affinis \\
\hline P5, apical seta/medial spine ratio & 1.1 & $1.1-1.6$ \\
Copulatory duct & Straight and wide & Straight or slightly curved and narrow \\
Caudal rami L/W ratio & 2.2 & $2.3-3.2$ \\
Dorsal caudal seta/outermost caudal seta ratio & 0.69 & $0.8-1.2$ \\
Spinules at implantation of lateral caudal seta & Absent & Present or absent \\
P4 ENP3, L/W ratio & 2.78 & 2.7 \\
P4 ENP3, inner spine/outer spine ratio & $1.15-1.35$ & 1 \\
\hline
\end{tabular}

P5, leg 5; L/W ratio, length-to-width ratio; P4, swimming leg 4; ENP3, endopodite 3. Data on M. affinis after Holyńska (2000). 
sia, collected by F.Y., June 20, 2011. Paratype, ZIN RN 55071,1 undissected copepodid of $5^{\text {th }}$ stage, in glycerol, from the same locality as the holotype.

Etymology: the name refers to the fact that this species seems to substitute E. speratus in the tropics.

Female (holotype): length: $1080 \mu \mathrm{m}$ without caudal setae, $1663 \mu \mathrm{m}$ with caudal setae. Body slender and yellowish in colour. Cephalothorax 1.1 times as long as wide, with maximum width near posterior margin. Pediger 5 with group of long hair-setae on lateral margin. Genital double-somite as long as wide, seminal receptacle well visible, shape typical for Eucyclops. Caudal rami (Fig. 5A

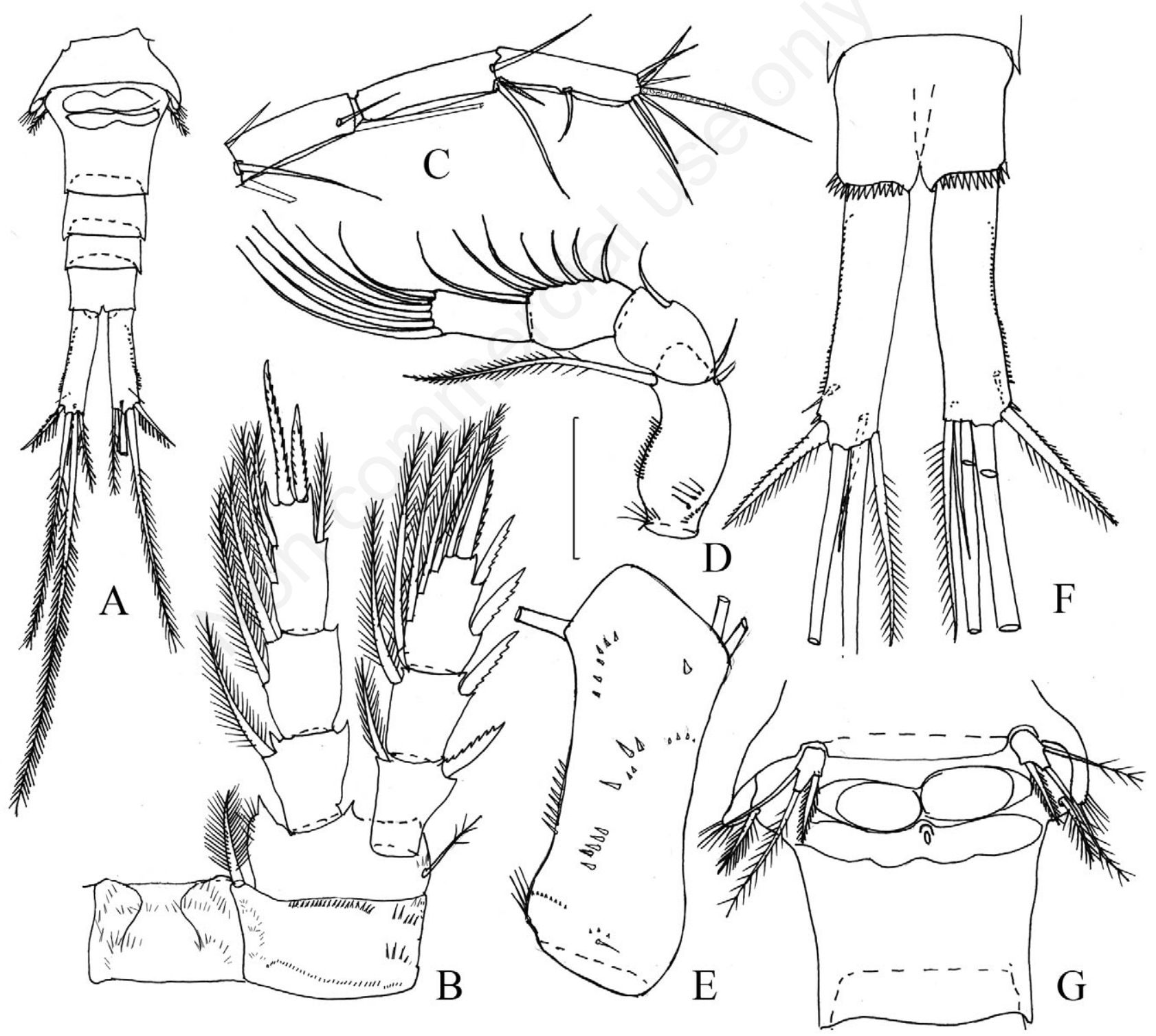

Fig. 5. Eucyclops troposperatus n. sp., pond in Bukitinggi, West Sumatra, female holotype. A) Abdomen, ventral; B) leg 4 caudal side; C) distal segments of antennule; D) antenna, caudal side; E) basipodite of antenna, frontal side; F) caudal rami, ventral; G) genital double-somite, ventral. Scale bars of $A)=120 \mu \mathrm{m} ; \mathrm{B}-\mathrm{D}, \mathrm{F}-\mathrm{G})=40 \mu \mathrm{m} ; \mathrm{E})=30 \mu \mathrm{m}$. 
and 5F) 4.3-4.5 times as long as wide, with a dorsal serra of 35-40 small and fine spinules, reducing in size from middle of serra to its anterior end where they go slightly dorsally almost disappearing from lateral side; caudal rami bearing 6 setae. Length proportion of 4 terminal caudal setae, from outermost to innermost: 83/378/583/116 $\mu \mathrm{m}$. Dorsal caudal seta as long as outermost terminal caudal seta, lateral seta about half length of dorsal seta (Fig. 5F). Outermost seta transformed into strong spine with short dense setules on internal side and small teeth on external side. At base of this seta, 3 small denticles inserted dorsally. Innermost seta with short dense setules on both sides (Fig. 5A and 5F).

Antennule 12-segmented reaching posterior margin of pediger 2, with smooth or slightly serrate hyaline membrane on $10^{\text {th }}-12^{\text {th }}$ segments, similar in construction to $E$. speratus s. lat. (Fig. 5C). Seta formula of segments: from proximal to distal segments: $8,4,2,6,4,2,2,3,2+a e, 2$, 2+ae, 7+ae. Antenna 4-segmented (Fig. 5D), composed of BAS and three-segmented ENP. Basipodite ornamentation similar to that in E. speratus s. lat.: on caudal side, 2 parallel lines of long and tiny spinules placed diagonally near base of segment next medial margin, no groups of long hair-setae [coded as 1 and 2 in Alekseev and Defaye (2011)] in distal part of segment (Fig. 5D); on frontal side, 1 row of fine denticles distally, row of 8 relatively large spinules in central part, inserted parallel to external (lateral) margin of segment, and several groups of tiny spinules as shown in Fig. 5E.

Mandible (not shown): gnathobase ending with 6 teeth and denticulate seta; palp (ENP) with 2 long setae and 1 short hairless seta. Maxillule (not shown) consisting of praecoxa, armed with 6 setae and 5 spines, and 2-segmented maxillulary palp bearing 7 setae, no ornamentation on palp. Maxilla (not shown) 5-segmented. Syncoxopodite partly divided into praecoxopodite with one endite (bearing 2 strong setae) and coxopodite with 2 endites, more proximal endite bearing one seta, and distal endite bearing 1 thin and 1 strong seta. Frontal surface of coxopodite smooth. Basipodite with claw-like endite armed with long lateral row of denticles and 2 setae; twosegmented ENP with $5(2+3)$ setae of different length. Maxilliped (not shown) 4 segmented: praecoxopodite + coxopodite with 2 strong setae in middle and small seta at distal end; basis with 2 setae of different length and 3 groups of strong hair-like setules next to lateral margin; first segment of ENP with 1 strong seta and group of hairlike setules inserted basally, second segment of ENP with strong spine and 2 hairless setae.

P1-P4 with 3-segmented rami. Spine and seta formula of P1-P4 EXP3 3.4.4.3, and 5.5.5.5, respectively. ENP3 bearing 5 setae and 1 apical spine in P1-P3, and 3 setae and 2 apical spines in P4. Coxal spine of P4 (Fig. 5B) homogeneously covered with dense long setules, similar to
E. speratus s. lat. P4 ENP3 elongated, 2.25 times as long as wide, with 2 strong spines at its end; inner spine 1.47 times as long as outer spine and 1.1 times as long as segment itself. Distal seta of P4 ENP not reaching end of nearest distal spines.

Intercoxal plate of leg 4 without prominences, and hairless on its free edge, as shown in Fig. 5B.

Leg 5 one-segmented with strong inner medial spine, outer seta 1.4 times as long as spine, middle seta about 2 times as long as spine (Fig. 5G).

Male: unknown.

Differential diagnosis: From the closely related $E$. speratus, the newly described species is clearly separated by the much shorter caudal rami [length-to-width ratio $(\mathrm{L} / \mathrm{W})=4.3-4.5$ vs 6-8 in E. speratus]; less reduced lateral serra on caudal rami; smaller body size; shorter outermost terminal caudal seta; more weak and short spine in leg 5 (P5). At the same time the two taxa share many other taxonomically important characters, such as: hyaline plates are smooth on the 3 distal segments of the antennule; hairlike setules are absent on caudal side of the antennal BAS; the same groups of spinules are present on the frontal side of the antennal BAS; long inner apical spine of P4 ENP3 (1.47 times as long as outer spine); coxal spine and inner outgrowth of the BAS of P4 homogeneously covered with dense long setules.

E. troposperatus can be distinguished from the congeners by unique combination of the characters including: caudal rami without spinules and hair-setae on dorsal and inner surfaces, distal setae of P4 ENP3 not reaching distal ends of nearest spines; P5 with spine clearly longer than the segment itself, smooth or slightly serrated hyaline membrane on $10^{\text {th }}-12^{\text {th }}$ segments of A1.

Ecology: Eucyclops troposperatus n. sp. was found in the littoral zone of a lake with macrophytes. Eucyclops is one of the species-rich and poorly known genera occurring in Indonesia, which has not been revised for a long time. At least five species live in SE Asia, and about the same number of taxa can occur in the neighbouring tropical regions, India and Australia. Hereafter, we provide an identification key to the Oriental and Australian species of the genus Eucyclops.

\section{Key to the Eucyclops species of SE Asia, Australia and India}

1. Caudal rami without line of denticles (serra) on lateral

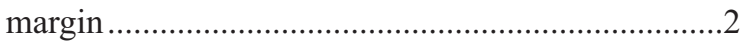

- Caudal rami with more or less developed serra ........3

2. Caudal rami very long, $\mathrm{L} / \mathrm{W}>8$; innermost and outermost caudal setae subequal

E. productus Kiefer, 1936 (North India)

- Caudal rami significantly shorter, $\mathrm{L} / \mathrm{W}<5$; innermost caudal seta about 1.5 times as long as outermost caudal seta..........E. linderi Lindberg, 1948 (Australia) 
3. Serra on caudal rami reduced, extending not more than $1 / 3$ length of rami. ...4

- Serra occupies not less than 1/2 length of caudal rami. . .11

4. Distal setae of P4 ENP3 very long, reaching distal ends of nearest spines .............................................5

- Distal setae of P4 ENP3 not so long ...................... 7

5. Distal inner spine of P4 ENP3 about 1.5 times as long as segment........E. thienemanni Kiefer, 1930 (Java)

- Distal inner spines of P4 ENP3 about as long as segment or shorter.....

6. P4 ENP3 inner spine about 0.7 times as long as segment...E. bryophilus Lindberg, 1950 (North India)

- P4 ENP3 inner spine about as long as segment E. ruttneri elburziensis Lindberg, 1941 (s. lat., part.) (South Afghanistan)

7. Medial spine of P5 very short, about as long as segment; innermost caudal seta about 3 times as long as outermost seta .....E. neocaledonicus Dussart, 1984

(New Caledonia)

- Medial spine of P5 clearly longer than segment; innermost caudal seta not more than 2 times as long as outermost caudal seta. ...8

8. Medial spine of P5 slender and longer than outer seta E. permixtus Kiefer, 1928 (Java)

- Medial spine of P5 strong, knife-like and shorter than outer seta.

9. Innermost caudal seta about twice as long as outermost caudal seta; P4 ENP with long inner setae reaching the distal end of inner apical spine

E. ruttneri Kiefer, 1933 (Java, Sumatra)

- Innermost caudal seta less than 1.6 times as long as outermost caudal seta; inner setae on P4 ENP not reaching the distal end of inner apical spine...........10

10. Caudal rami $\mathrm{L} / \mathrm{W}=4-5$, parallel

E. defectus Lindberg, 1938 (India)

- Caudal rami $\mathrm{L} / \mathrm{W}=3.75$, divergent.

E. farsicus Lindberg, 1941(Afghanistan)

11. Medial spine of P5 reduced, as long as segment; dorsal caudal seta about twice of outermost caudal seta ......

E. nichollsi Brehm, 1950 (Tasmania; Australia (NSW, Queensland): E. $n$. baylyi Morton, 1990)

- Medial spine of P5 clearly longer than segment; dorsal caudal seta not more than 1.3 times as long as outermost caudal seta.

12. Caudal rami $\mathrm{L} / \mathrm{W}=7-8$ and parallel, lateral serra with very small and dense denticles

E. spatulatus Morton, 1990 (Australia)

- Caudal rami L/W not more than 6, usually less, and more or less divergent. 13

13. Distal spines of P4 ENP3 more wide in distal end; innermost caudal seta about twice of outermost caudal seta, latter one inserted more laterally separated by gap from other terminal caudal setae
E. euacanthus (G.O. Sars, 1909) (Pantropical; Myanmar: E. e. birmanus Lindberg, 1949)

- Distal spines of P4 ENP3 of normal construction; innermost caudal seta less than 2 times (usually less than 1.5 times) as long as outermost caudal seta, latter one usually inserted more or less close to other terminal caudal setae .14

14. Medial spine of P5 weak, and at least 2 times shorter than outer seta.

E. semidenticulatus Lindberg, 1940 (India)

- Medial spine of P5 better developed .....................15

15. Antennule with serrated hyaline plate on 3 terminal segments; caudal rami strongly divergent

E. microdenticulatus Lindberg, 1940 (India)

Antennule with smooth hyaline plate on 3 terminal segments; caudal rami slightly divergent or parallel.......16

16. Antennal BAS with two groups (position 1,2) of long hair-setae on caudal side.... .17

- Antennal BAS without long hair-setae (position 1,2) on caudal side ..E. troposperatus Alekseev et Yusoff

(West Sumatra, highlands)

17. P4 coxal spines homonomously setulose (with long and dense setules) on both sides

E. agiloides (Sars, 1909)

(Pantropical; in Australia: E. a. australiensis Morton, 1990)

- P4 coxal spines armed with short strong denticles on inner edge, outer edge almost smooth, or denticles present apically only ....E. serrulatus (Fischer 1853) (Palearctic, in the tropics only as introduced species )

\section{Sulawesi: Cyclopoida}

In the pelagic zooplankton of the six lakes that we investigated in Sulawesi, only four Cyclopoid species were found (Tab. 4).

\section{Tropocyclops matanoensis Defaye, 2007}

Our record of Tropocyclops matanoensis Defaye, 2007, recently described as a supposedly endemic form in lake Matano, is the second finding of this species after the original description. This species differs from most other Tropocyclops species in several important characters, such as the P5 armature (two instead of three elements). Similar structure of the P5 is only known in Tropocyclops jamaicensis Reid et Janetzky, 1996, found in bromeliad leaves from Jamaica.

Since Kiefer's analytical publication (1927), the generic diagnoses of the cyclopid genera are largely based on the segmentation and armament of the P5. In Tropocyclops, after Kiefer (1927), the generic characters are connected to the P5 morphology as well: P5 is consisting of one free segment, a triangular plate, bearing 3 external sub-equal elements, a terminal seta, a very long internal spiniform seta and lateral seta. After the finding 
Tab. 4. Species, sex, life stage, and number of specimens examined.

\begin{tabular}{|c|c|c|c|}
\hline Lake (island) & Species found & Sex/life stages & No. \\
\hline Selica (Sulawesi) & Thermocyclops crassus length $550 \mu \mathrm{m}$ & $\begin{array}{l}\text { Female } \\
\text { Male }\end{array}$ & $\begin{array}{l}5 \\
1\end{array}$ \\
\hline \multirow[t]{3}{*}{ Poso (Sulawesi) } & Neodiaptomus lymphatus & $\begin{array}{c}\text { Female } \\
\text { Male } \\
\text { Copepodid V } \\
\text { Copepodid IV }\end{array}$ & $\begin{array}{l}1 \\
3 \\
3 \\
1\end{array}$ \\
\hline & Thermocyclops crassus length $550 \mu \mathrm{m}$ & Female & 1 \\
\hline & Thermocyclops crassus length $730 \mu \mathrm{m}$ & Female & 2 \\
\hline \multirow[t]{2}{*}{ Matano (Sulawesi) } & Eodiaptomus matanensis & $\begin{array}{c}\text { Female } \\
\text { Male } \\
\text { Copepodid V }\end{array}$ & $\begin{array}{l}7 \\
5 \\
1\end{array}$ \\
\hline & Tropocyclops (Defayeicyclops) matanoensis & Female & 4 \\
\hline \multirow[t]{2}{*}{ Mahalona (Sulawesi) } & Eodiaptomus matanensis & $\begin{array}{c}\text { Female } \\
\text { Male } \\
\text { Copepodid V }\end{array}$ & $\begin{array}{l}1 \\
3 \\
4\end{array}$ \\
\hline & Mesocyclops aequatorialis similis & $\begin{array}{c}\text { Female } \\
\text { Male } \\
\text { Copepodid V }\end{array}$ & $\begin{array}{l}4 \\
1 \\
1\end{array}$ \\
\hline Tondano (Sulawesi) & Phyllodiaptomus praedictus sulawesensis $\mathrm{n}$. ssp. & $\begin{array}{c}\text { Female } \\
\text { Male } \\
\text { Copepodid V }\end{array}$ & $\begin{array}{l}4 \\
4 \\
4\end{array}$ \\
\hline \multirow[t]{2}{*}{ Towuti (Sulawesi) } & Eodiaptomus wolterecki & $\begin{array}{c}\text { Female } \\
\text { Male } \\
\text { Copepodid V }\end{array}$ & $\begin{array}{l}4 \\
2 \\
1\end{array}$ \\
\hline & Mesocyclops sp. & Copepodid III-V & 13 \\
\hline Laguna (Ternate) & Mesocyclops sp. & $\begin{array}{l}\text { Copepodid V } \\
\text { Male }\end{array}$ & $\begin{array}{l}1 \\
3\end{array}$ \\
\hline Tolire (Ternate) & Thermocyclops crassus length $850 \mu \mathrm{m}$ & $\begin{array}{c}\text { Female } \\
\text { Copepodid V }\end{array}$ & $\begin{array}{l}4 \\
3\end{array}$ \\
\hline
\end{tabular}

of T. jamaicensis (as an exception with 2 elements on P5), Reid and Janetzky (1996) modified the generic diagnosis by addition of except T. jamaicensis $n$. sp. lacking lateral seta. The finding and description of a second species with the same modification of P5, and the similarity in several other taxonomically important morphological characters support our hypothesis that specific P5 construction in T. jamaicensis was not an exception within the genus, but rather an important modification of this feature, reflecting phylogenetically deeper separation. These two species lacking the lateral seta on P5 and the posterolateral hair-like spinules on pediger 5 indeed constitute a separate group, differing from most other genera of the Eucyclopinae. At the same time, $T$. matanoensis differs from T. jamaicensis in several characters, such as the presence of only one seta on the antero-distal corner of the antennal BAS, the number of setae on the second endopodal segment of the antenna ( 8 in T. matanoensis,), the spine formula of the swimming legs (3.4.4.3. in T. matanoensis, 3.4.3.3. in T. jamaicensis), and the shape of the seminal receptacle
(Defaye, 2007). Obvious separation between these species in several important characters might indicate that other new species will be also found and described in this group when tropical copepod biodiversity receives more attention. The difference in P5 construction, which is typically a genus-specific character as well as the specific construction of receptaculum seminis, are essential enough to erect a new subgenus and separate these two very special species from other members of the species-rich genus Tropocyclops which currently comprises about 40 species and subspecies.

\section{Family Cyclopidae Rafinesque, 1815}

Subfamily Eucyclopinae Kiefer, 1927

Genus Tropocyclops Kiefer, 1927

Subgenus Defayeicyclops Alekseev et Vaillant n. subg.

Type species: Tropocyclops (Defayeicyclops) matanoensis Defaye, 2007 


\section{Systematics}

Female: medium-sized cyclopid $(600-700 \mu \mathrm{m})$ widest at the posterior part of cephalothorax (Fig. 6). Pediger 5 without long posterolateral setules, but row of short spinules present on lateral margins (Fig. 6E, arrow). Genital double-somite elongated and about 1.5 times longer than wide, with butterfly-like shaped seminal receptacle in anterior part. Anal operculum smooth without denticles or hair-setae. Caudal rami (Fig. 6B) rather short, about 2 times longer than wide, without hair-like spinules or denticles on lateral margins and on dorsal and ventral surfaces; with the usual 6 setae. Caudal setae: lateral seta inserted near middle of lateral margin of caudal rami; out- ermost and innermost setae of similar length and slightly longer than ramus; dorsal seta about twice the length of caudal rami; inner median terminal seta twice the length of dorsal seta. Antennule 12-segmented and long, reaching third pedigerous somite; last 3 segments with thin hyaline lamella. Antenna 4-segmented, composed of BAS and 3-segmented ENP. Labrum composed of 12 teeth and covered externally with long, distal hairs. Mouth appendages as usual in Tropocyclops. P1-P4 (Fig. 6C) with 3-segmented rami. Segments and spines slender. P1 BAS with 1 long spine on inner margin. P5 one-segmented, more or less oval in lateral view, ornamented laterally with small, distal row of short spinules; and bearing 1 long
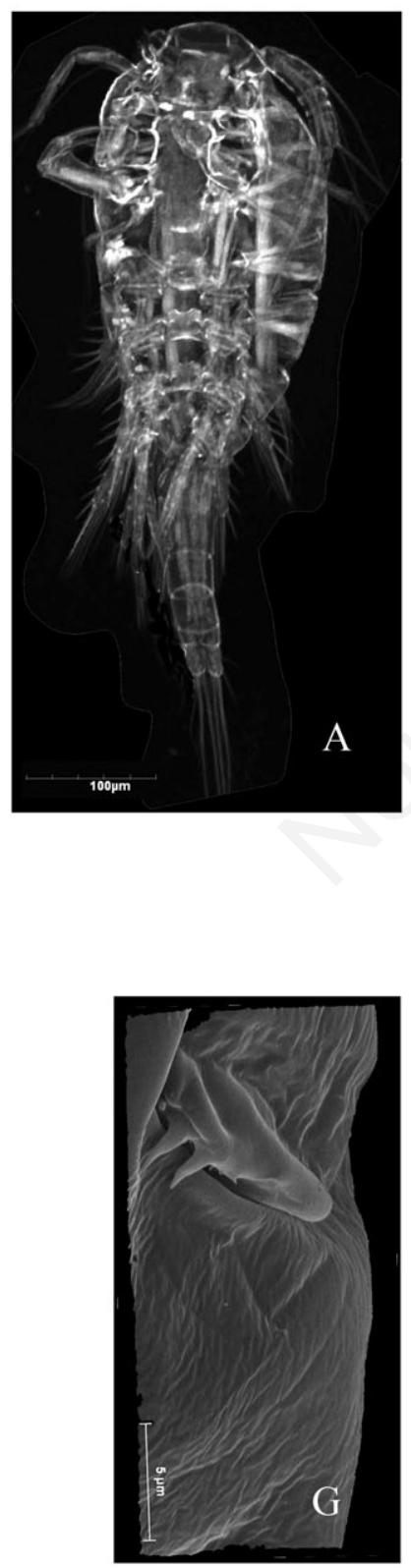
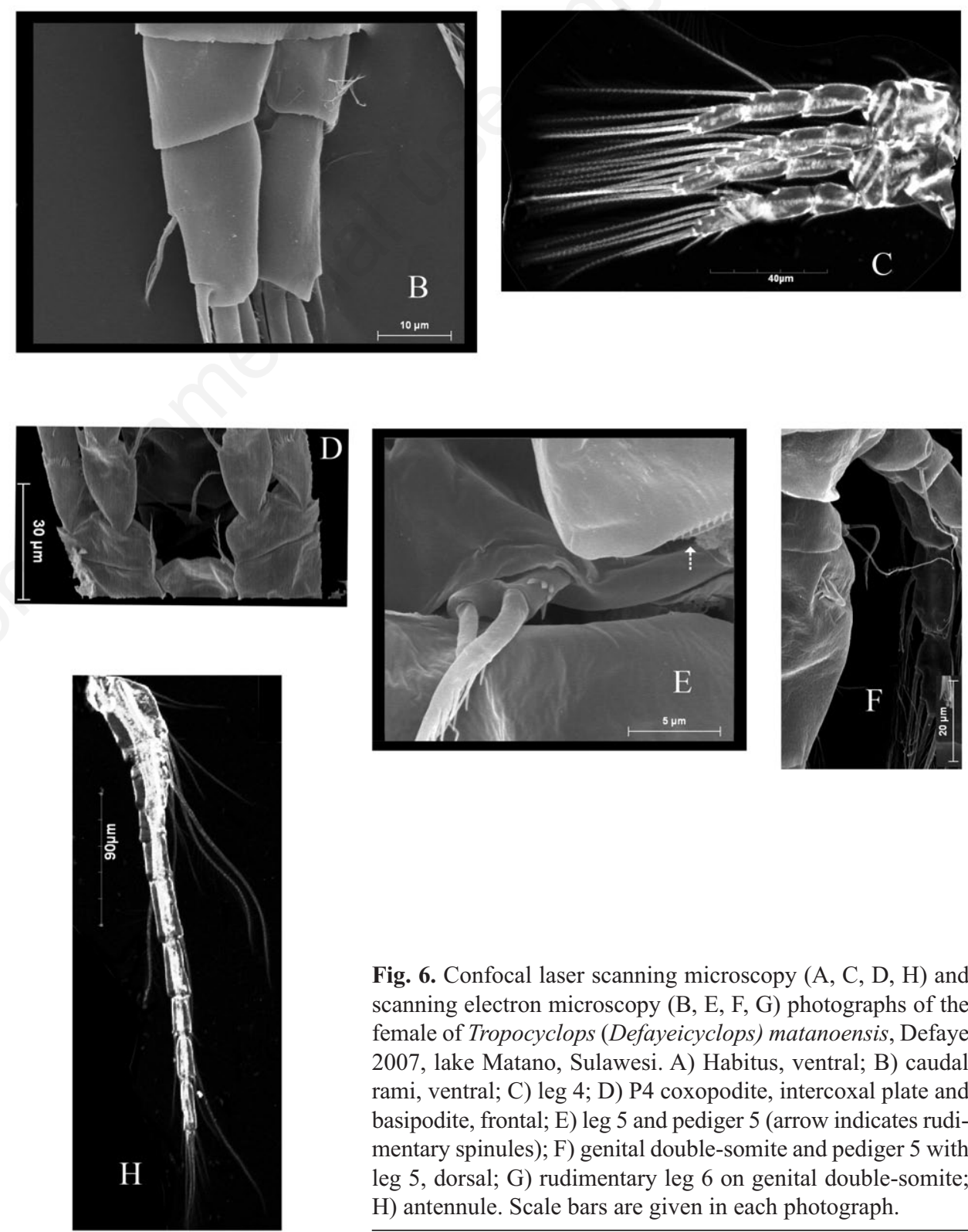
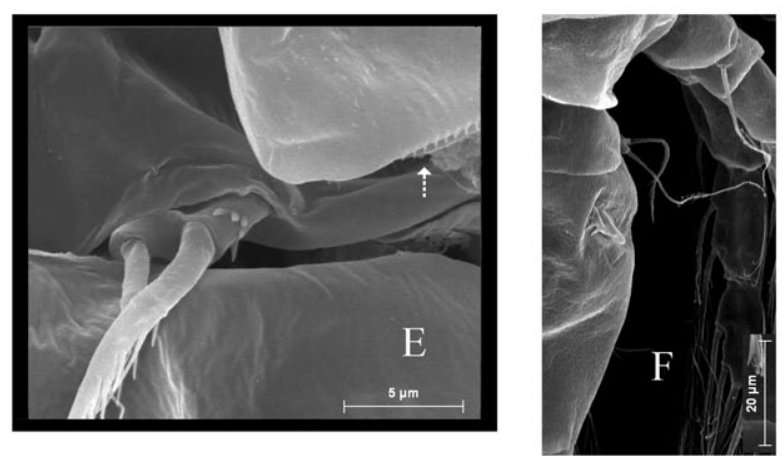

Fig. 6. Confocal laser scanning microscopy (A, C, D, H) and scanning electron microscopy $(\mathrm{B}, \mathrm{E}, \mathrm{F}, \mathrm{G})$ photographs of the female of Tropocyclops (Defayeicyclops) matanoensis, Defaye 2007, lake Matano, Sulawesi. A) Habitus, ventral; B) caudal rami, ventral; C) leg 4; D) P4 coxopodite, intercoxal plate and basipodite, frontal; E) leg 5 and pediger 5 (arrow indicates rudimentary spinules); F) genital double-somite and pediger 5 with leg 5, dorsal; G) rudimentary leg 6 on genital double-somite; $\mathrm{H})$ antennule. Scale bars are given in each photograph. 
spine inserted on the inner margin subapically and 1 apical seta, setae subequal (Fig. 6E).

Male (not shown): antennule geniculate, 16-segmented. Segmentation and armature of P1-P4 identical to those in female. P5 one-segmented with 2 appendages similar to that of female, but with longer seta and a spine. P6 composed of 3 elements inserted close to each other on a small plate: 1 strong inner spine, 1 small and thin median seta, and 1 outer seta longer than inner spine.

\section{Morphological affinities}

Based on P5 morphology only, the new subgenus might be placed in the Cyclopinae subfamily, as the free (distal) segment of P5 bears two setae in the subgenus Defayeicyclops. At the same time, it shares several characters with Tropocyclops such as: the shape and size of the body, the relative length and segmentation of A1, the segmentation and spine/seta armament of the swimming legs. The inner margin of the BAS of P4 is rounded in Defayeicyclops, similarly to Tropocyclops species, yet differentiating it from Eucyclops and most Cyclopinae species.

Defayeicyclops differs from Tropocyclops $\mathrm{s}$. str. in the characters as follows: i) the fifth leg is armed with two elements only (bearing three elements in Tropocyclops s. str.); and ii) anterior part of the seminal receptacle is butterflyshaped (with horn-like processes in Tropocyclops s. str.).

Defayeicyclops n. subg. currently comprises 2 species: T. jamaicensis Reid et Janetzky, 1996 from Jamaica and T. matanoensis Defaye, 2007 from Sulawesi. The representatives of the new subgenus were found in highly separated regions (tropical islands in the Pacific and Atlantic oceans).

\section{Thermocyclops crassus (Fischer, 1853)}

The population of this species from lake Tolire was very similar to the European representatives of $T$. crassus in their body size ( $850 \mu \mathrm{m}$ for adult female), the taxonomically important characters, and even in the fine morphological details. They had no discernable difference from the topotype population of this species (St. Petersburg, Russia).

In lake Poso, we found two populations of Thermocyclops crassus differing in size only. Along with females of $T$. crassus about $750 \mu \mathrm{m}$ length that well fit the smallest individuals from the terra typica population (Peterhoff, Russia), we also found females about $550 \mu \mathrm{m}$ in length. Only this minor form was present in lake Selica.

\section{Mesocyclops aequatorialis similis Van de Velde, 1984}

Mesocyclops aequatorialis similis Van de Velde, 1984 was found in lake Mahalona, situated between the two largest Malili lakes, Matano and Towuti (Fig. 1B). The individuals we have examined did not differ significantly from either the Asian (Kiefer Coll., slide 04585-4589) or the African specimens (Kiefer Coll., slides 04724, 04725) of M. aequatorialis (Africa is terra typica of M. aequatorialis similis).

\section{Mesocyclops sp.}

In lake Laguna (Ternate island) and lake Towuti (Sulawesi island; downstream of lake Mahalona) we found a Mesocyclops represented by only copepodid stages and males, which could not be identified on species level (Tab. 4). As lake Towuti is the next downstream lake in the Malili lake system following lake Mahalona, where $M$. aequatorialis similis was found, we speculate that Mesocyclops $s p$. in lake Towuti belongs to the same species migrating from the upstream river mouth (possible invasion site; see Discussion).

\section{Sulawesi: Calanoida}

In our Sulawesi samples we found three diaptomids belonging to an endemic complex described by Brehm (1933) from Woltereck's collection. These rare diaptomids have not been described sufficiently, therefore some illustrations and brief descriptions are provided here. In the identification of the Eodiaptomus species, we compared our material to the reference slides of Eodiaptomus wolterecki from the F. Kiefer's collection (Karlsruhe Museum, Germany).

\section{Neodiaptomus lymphatus (Brehm, 1933) (Fig. 7)}

We found the species ( 1 female and 3 males) in lake Poso, close to the small lake Tempe, from where Brehm originally described it. In a revision of the genus, Reddy (1994) mentioned the lack of information on some taxonomically important morphological details in both sexes. We add more information on those characters, also because they are in some contradiction with the descriptions of Brehm (1933) and Reddy (1994).

Female: body length $1000 \mu \mathrm{m}$ without, and $1135 \mu \mathrm{m}$ with caudal setae (Fig. 7D-I). A1 length $989 \mu \mathrm{m}$, reaching distal end of caudal rami. Fifth pedigerous somite with small wings armed with 2 processes on each wing. Genital somite symmetrical, and equal in length to urosome including caudal rami, laterally with two small spines equal in size (Fig. 7H). Caudal rami asymmetrical with left ramus 1.7 times as long as wide and right ramus 1.2 times as long as wide, with strong but relatively short caudal setae, and with sparse and fine hair-like setules along outer margin (Fig. 7G). P1-P4 rami 3-segmented, except P1 ENP (2-segmented), spine/seta formula presented in Tab. 5. P5 (Fig. 7D): coxopodite with triangular lateral spine, sensor seta of BAS very short, ENP two-segmented (one-segmented in Brehm, 1933 and Reddy, 1994), clearly shorter than first exopodal segment, with few rel- 


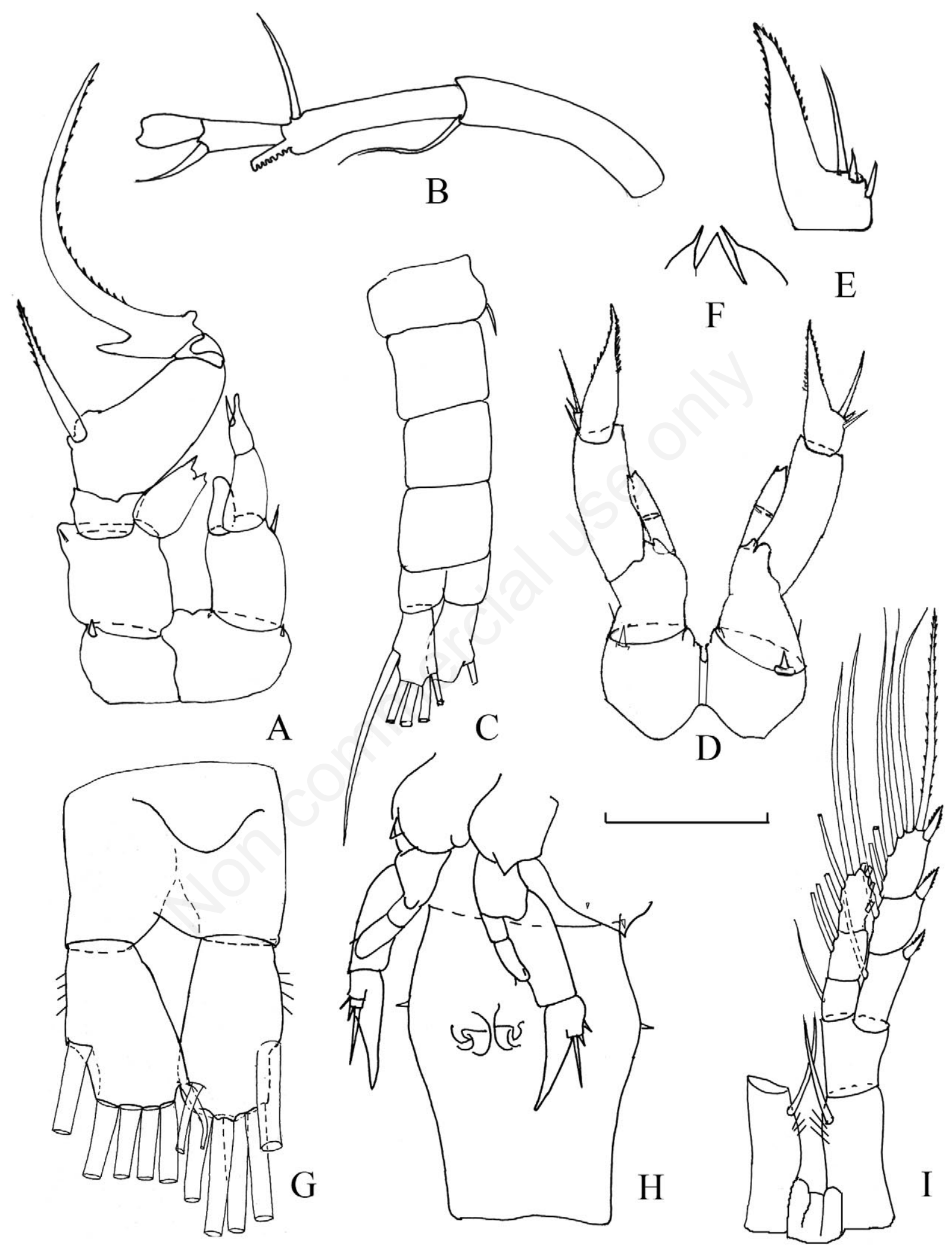

Fig. 7. Male (A-C) and female (D-I) of Neodiaptomus lymphatus Brehm, 1933, lake Poso, Indonesia. A) Leg 5 ventral; B) distal segments of antennule; C) urosome; D) leg 5; E) distal segment of exopodite of leg 5; F) rostrum; G) caudal rami; H) genital segment with leg 5, lateroventral; I) leg 4. Scale bars of $A)=100 \mu \mathrm{m} ; C)=200 \mu \mathrm{m} ; \mathrm{B}, \mathrm{D}, \mathrm{E}, \mathrm{H}, \mathrm{I})=80 \mu \mathrm{m} ; \mathrm{G})=60 \mu \mathrm{m}$. 
Tab. 5. Spine/seta armament of the swimming legs of Neodiaptomus lymphatus (Brehm, 1933).

\begin{tabular}{|c|c|c|c|c|c|c|}
\hline \multirow[b]{2}{*}{ Segments } & \multicolumn{3}{|c|}{ Exopodite } & \multicolumn{3}{|c|}{ Endopodite } \\
\hline & 1 & 2 & 3 & 1 & 2 & 3 \\
\hline P1 & $\mathrm{I} / 1$ & $-/ 1$ & $\mathrm{II} / 4$ & $-/ 1$ & - & $-/ 6$ \\
\hline P2 & $\mathrm{I} / 1$ & $\mathrm{I} / 1$ & $\mathrm{II} / 5$ & $-/ 1$ & $-/ 2$ & $-/ 7$ \\
\hline P3 & $\mathrm{I} / 1$ & $\mathrm{I} / 1$ & $\mathrm{II} / 5$ & $-/ 1$ & $-/ 2$ & $-/ 7$ \\
\hline P4 & $\mathrm{I} / 1$ & $\mathrm{I} / 1$ & $\mathrm{II} / 5$ & $-/ 1$ & $-/ 2$ & $-/ 7$ \\
\hline
\end{tabular}

Roman numbers indicate spines, while Arabic numbers indicate setae.

atively strong spinules apically; EXP: claw with very fine denticles on both sides, lateral spine of second exopodal segment relatively long, third segment partly fused, with two spines, longest not reaching beyond end of claw.

Male: body length 1100-1150 $\mu \mathrm{m}$, left antennule with long saw-like process but shorter than that in Brehm's drawing, just reaching middle of next segment (Fig. 7AC). Right leg 5: BAS with short spine on distal lateral outgrowth, second exopodal segment oval in shape with strong and straight lateral spine inserted in large distance from end claw which is long and sickle-shaped with long row of strong denticles on inner edge (Fig. 7A). Endopodite: one-segmented wide, extending to middle of second EXP segment, with 2 sharpen processes distally. Left leg 5: baspodite with strong spine laterally, first exopodal segment conical and significantly longer than second segment bearing pincer-like structure in distal end. Endopodite: one-segmented oval and wide (narrow in Brehm's drawing) with group of short spinules distally. Some other details of male morphology can be found in Fig. 7A-C.

\section{Eodiaptomus wolterecki Brehm,1933}

(Fig. 8A, 8C, 8F, 8H)

It was found in the lake Towuti (type locality).

Female: body length $1000 \mu \mathrm{m}$ without, and $1135 \mu \mathrm{m}$ with caudal setae, A1 length $989 \mu \mathrm{m}$, just reaching distal end of caudal rami (Fig. 8C and 8H). Fourth pedigerous somite with group of small spines on dorsal side (Fig. $8 \mathrm{H})$. Fifth pedigerous somite round shaped without wings, armed with 2 short processes on each side. Genital somite symmetrical, laterally with two small spines, right spine slightly longer than left one. Caudal rami symmetrical with dense fine hair-like setules along outer and inner margins. Leg 5 (Fig. 8C): Coxopodite without lateral processes, oval in shape. Endopodite one-segmented with short sensory setae, elongated, equal in length to first exopodal segment, with few setules distally. Exopodal claw with fine denticles on both sides, lateral spine of second exopodal segment short, third segment fused, with single (longest) spine presented. This spine relatively short and not reaching middle of claw.
Male: about the same size as female. Antepenultimate segment produced into long sharpen process (Fig. 8F). Right leg 5 (Fig. 8A): ENP one-segmented, elongated as long as first exopodal segment with few short spinules distally; second exopodal segment less than twice of first segment length with relatively weak lateral spine inserted near strong distal claw that not more than 1.5 times as long as distal segment length. Left leg 5: ENP elongated reaching with single but relatively strong distal spine-like process to distal end of EXP. Exopodite reaching to middle of EXP 2 of right leg.

\section{E. matanensis Brehm 1933 (Fig. 8B, 8D, 8E, 8G)}

\section{Syn: Eodiaptomus wolterecki matanensis Brehm, 1933}

We found this species in the type locality (lake Matano) and in lake Mahalona (Tab. 4). It must be mentioned that among Kiefer slides NN 04026-04027 from lake Towuti, several individuals were named as E. matanensis while the typical form from the same lake had the name $E$. wolterecki (slides NN 04022-04026 and 04028). The significant morphological differences between $E$. wolterecki s. str. and Eodiaptomus wolterecki matanensis prompted us to elevate the matanensis-form from a subspecies to species rank. This decision got further support from the analyses of the COI sequences (Fig. 9).

Female: body length $1000 \mu \mathrm{m}$ without, and $1135 \mu \mathrm{m}$ with caudal setae, A1 length $989 \mu \mathrm{m}$, reaching significantly beyond distal end of caudal rami (Fig. $8 \mathrm{G}$ and $8 \mathrm{D}$ ). Fifth pedigerous somite without wings. Genital somite symmetrical, laterally with two small spines equal in size. Caudal rami symmetrical with dense fine hair-like setules along outer and inner margins. Leg 5 (Fig. 8D): coxopodite without lateral processes, oval in shape. Basipodite elongated, shorter than first EXP segment. Exopodal claw with fine denticles on both sides, third exopodal segment fused, with single (longest) seta reaching middle of claw. Endopodite one-segmented with few setules distally.

Male: body length subequal to female (Fig. $8 \mathrm{~B}$ and $8 \mathrm{E})$. Antepenultimate segment produced into long but not acute process, slightly bent in distal part (Fig. 8E). Right leg 5 (Fig. 8B): one-segmented ENP elongated, clearly longer than first exopodal segment, with few short spin- 
ules distally; second exopodal segment twice of first segment in length with more robust (compared to previous species) lateral spine inserted at some distance from strong distal claw which less than twice longer than distal segment. Left leg 5 (Fig 8B): ENP elongated not reaching to distal end of EXP. Exopodite with short distal process extending to first third of EXP 2 of right leg.

The morphological differences between $E$. woltereck $i$ (Ew) and E. matanensis (Em) can be summarised as follows. In female: i) A1 just reaching distal end of caudal rami (Ew)/reaching well beyond distal end of caudal rami (Em); ii) P5 ENP as long as first exopodal segment (Ew)/clearly shorter than EXP (Em); iii) longest spine of P5 EXP3 not reaching middle of claw (Ew)/reaching middle of claw (Em). In male: i) antepenultimate segment of
A1 produced into long acute and straight process $(\mathrm{Ew}) /$ produced into blunt process which is slightly bent in distal part process (Em); ii) Right leg 5: ENP clearly longer than first exopodal segment (Em)/as long as first exopodal segment (Ew); iii) Left leg 5: EXP with distal process not reaching middle of EXP2 of right leg $($ Em)/reaching middle of EXP 2 of right leg (Ew).

Among the diaptomids found in lake Tondano, one form appeared to be a new species to science (description of the new species is given below). To better delineation of the species the morphological characters were checked in both sexes. For comparison, we examined the specimens of Phyllodiaptomus annae (Apstein, 1907) from F. Kiefer's collection (Karlsruhe Museum, Germany).
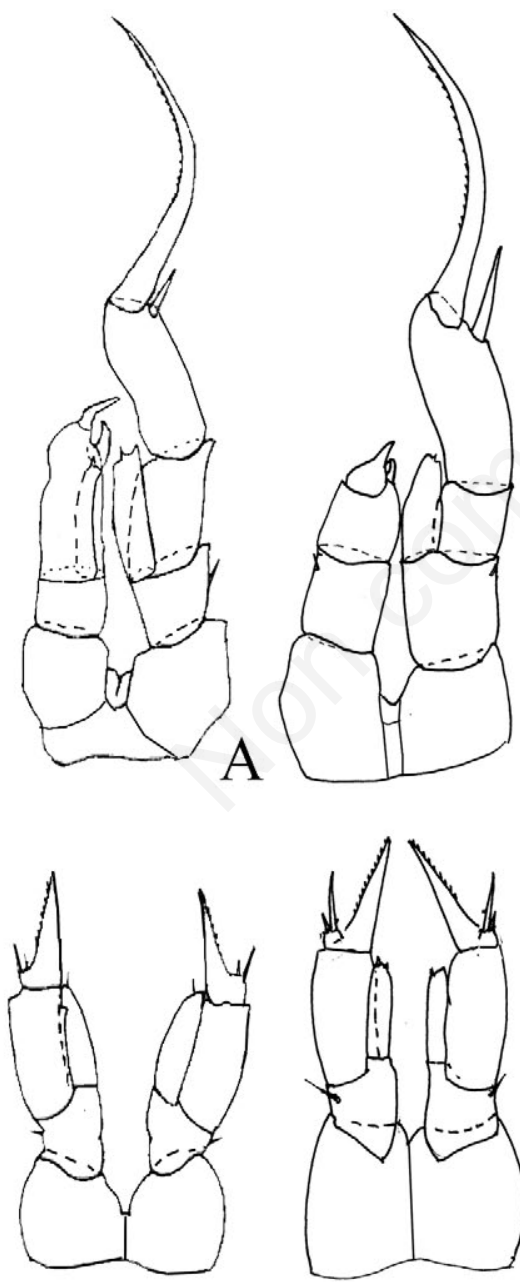

C

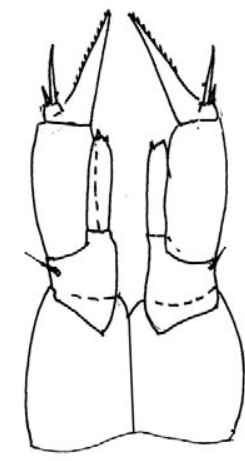

$\mathrm{D}$
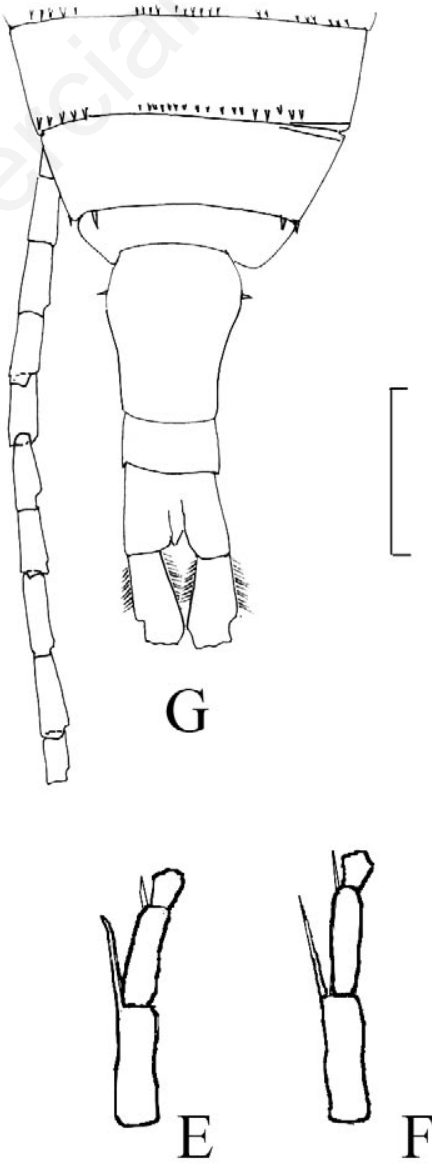

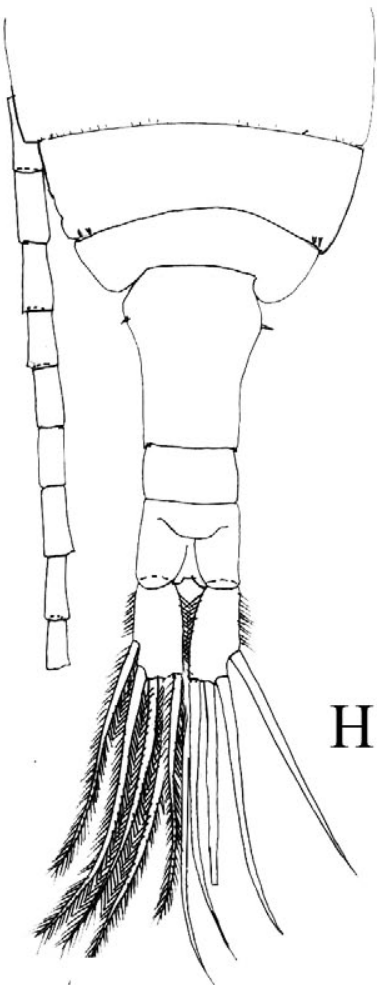

$\mathrm{H}$

Fig. 8. Eodiaptomus wolterecki Brehm, 1933 (A,C,F,H) from lake Towuti and Eodiaptomus matanensis Brehm, 1933 (B,D,G,E), from lake Matano, both Sulawesi. A,B) male, leg 5; C,D) female leg 5; E,F) male distal segments of geniculate antennule; G,H) female last thoracic segments and abdomen, dorsal. Scale bars of $A, E, F)=80 \mu \mathrm{m} ; B)=70 \mu \mathrm{m} ; C, D)=200 \mu \mathrm{m} ; \mathrm{D})=80 \mu \mathrm{m}$. 


\section{Superfamily Diaptomoidea Baird, 1850}

\section{Family Diaptomidae Baird, 1850}

\section{Genus Phyllodiaptomus Kiefer, 1936}

P. praedictus sulawesensis Alekseev et Vaillant n. ssp. (Figs. 10-13)

\section{Systematics}

Type material: holotype, ZIN RN 55058, a female dissected on 1 slide; from lake Tondano, North Sulawesi, Indonesia (GPS 1'13'09.0'N, 12453'39.6”'E), collected by James Vaillant, June 9, 2009; allotype, ZIN RN 55059, a male dissected on 1 slide; from the same sample as the holotype; other paratypes, ZIN RN 55060-62, 3 females and 6 males from lake Tondano, North Sulawesi, Indonesia, dissected on 3 slides ( 3 individuals per 1 slide), 4 undissected CV larvae, preserved in ethanol.

COI barcode accession no. JN183939-JN183940.

Etymology: the new species is named after the Sulawesi island, where it appears to be endemic.

Female (holotype): body transparent, with slight asymmetry in shape of genital double-somite and length of lateral wing of fifth pedigerous somite (Fig. 10B). Length measurements: full body length without caudal setae $1045 \mu \mathrm{m}$, with caudal setae $1220 \mu \mathrm{m}$; cephalosome and 4 free thoracic segments $750 \mu \mathrm{m}$. Urosome $295 \mu \mathrm{m}$, genital double-somite $155 \mu \mathrm{m}, 2$ succeeding urosomites 35 and $50 \mu \mathrm{m}$, caudal rami $55 \mu \mathrm{m}$. Cephalosome as long as wide, with a maximum width close to middle, frontal part of cephalosome oval. Rostrum with 2 equal spines (Fig. 11C).

Lateral wings of fifth pediger asymmetrical, left wing more narrow, index of asymmetry (Iass) 1.39, with 2 spines on each wing. Genital double-somite 1.7 times as long as wide, asymmetrical (Iass=1.33), genital spine of different length (Iass=1.4), and laterally directed. Caudal rami 1.5 times as long as wide, with hair-setae on medial and lateral margin.

Antennule consists of 25 segments, $1155 \mu \mathrm{m}$ length, extending to end of caudal setae. Armature formula of antennule as follows: $\mathrm{ae}+1, \mathrm{ae}+3$, ae $+1,1, \mathrm{ae}+1,1, \mathrm{ae}+1$, ae +1, ae $+2,1,1$, ae $+2,1$, ae $+1,1$, ae $+1,1,1$, ae $+1,1,1$, $\mathrm{ae}+1$, ae +1 , ae $+1,4$. Antenna (Fig. 11B) biramous, composed of 1-segmented protopod, 2-segmented ENP, and 7-segmented EXP with 1, 3, 1, 1, 1, 1, 3 setae, starting from first segment. First endopodal segment with 2 setae, second with 9 setae laterally, and 7 setae at distal end.

Mandible (not shown) composed of coxa with gnatobase, one of its teeth (outermost) significantly larger than others and separated from them. Coxa in middle with biramous mandibular palp, basis with 4-segmented EXP and 2-segmented ENP. Distal segment of EXP with 3 subequal setae, other segments bearing long, single seta each. Distal segment of ENP (not shown) with 7 long setae and 2 short seta, first segment with 4 long setae.

Maxillule (Fig. 11E) biramous and composed of precoxa with medial arthrite bearing 7 strong claw-like spines, 7 long bent setae and 2-3 short setae; coxopodite with 2 endites bearing 2 long setae each. Basis with 1segmented EXP with 6 long sub-equal setae and 1-segmented ENP bearing 9 long setae. Maxilla (Fig. 11D) uniramous, composed of precoxa with 2 endites; bearing 2 long and 1 short setae each, coxa with 2 endites bearing 2 long and 1 short setae each, BAS with 2 long and 1 short setae, and 3-segmented ENP, first and second segment with 2 long and 1 short setae each, and third (distal) segment with 3 long and 1 short setae.

Maxilliped (Fig. 11F) uniramous and 8-segmented, composed of syncoxa (precoxa+coxa) with 4 endites bearing from proximal to distal 1, 2, 4, 4 setae respectively; basis with 3 long setae followed by 6-segmented ENP armed with 2, 3, 2, 2, 2, and 4 (distally) seta.

Swimming legs P1-P4 (Fig. 11G-I) consisting of cox-

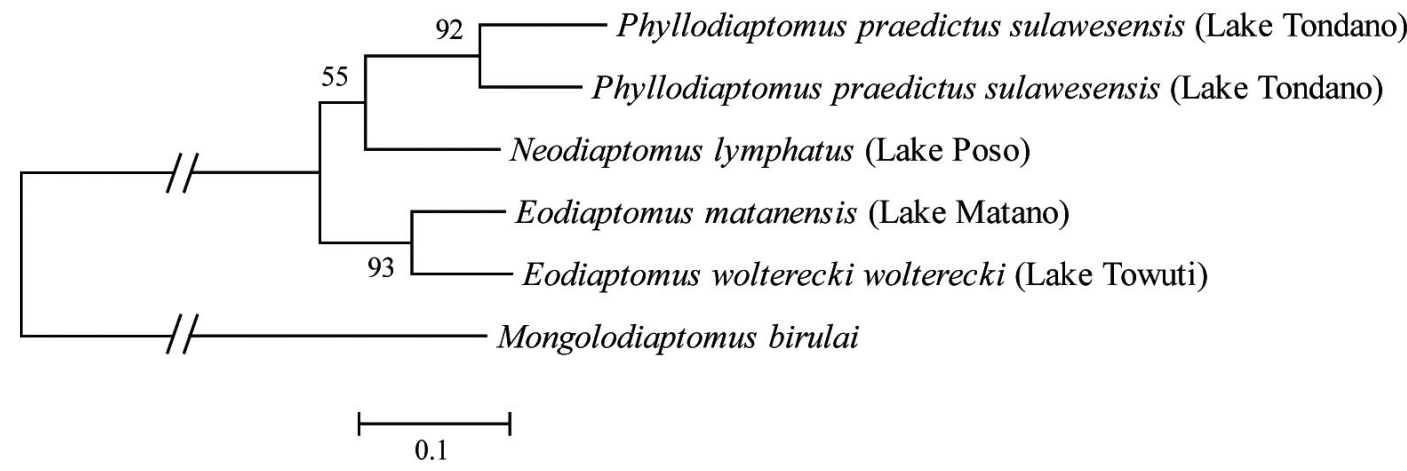

Fig. 9. Maximum-likelihood phylogenetic reconstruction of Sulawesi diaptomids. Numbers above nodes indicate bootstrap values. Scale bar represents number of substitutions per site. 
opodite and BAS and 3-segmented EXP and 2- (P1) or 3segmented ENP (P2-P4). Coxopodites with inner spines, connected with smooth intercoxal plates. First exopodal segments in each leg with 1 spine outside and 1 seta inside. Second exopodal segment in P1 without external spine. Distal (third exopodal) segment in legs 1-4 with one short and one very long spine. Distal segment of ENP on P1 with 6 setae, on P2-P4 with 7 setae.

Rudimentary P5 (Figs. 11J, 11K and 12F) biramous, consisting of coxopodite, BAS and 3-segmented EXP and 2 -segmented ENP. Coxal spines strong and conical in shape, equal on both sides, sensory basal setae long, extending beyond third exopodal segment. Third exopodal segment small but well-defined, with 2 dissimilar spines, long spine not extending to end of inner outgrowth of sec- ond segment. Lateral spine on second exopodal segment relatively long and well defined. Outgrowth (claw) with dense hair-seta on inner lateral side and in some individuals with few hair-seta on outer side (Fig. 11K, arrowed). Endopodite two-segmented with set of short and two long spinules at distal end (Fig. 11J, arrowed). Egg sac with up to 20 eggs.

Male: body length $1115 \mu \mathrm{m}$ without and $1315 \mu \mathrm{m}$ with caudal setae, colourless (Fig. 10A). Cephalosome elongated 1.35 times as long as wide, with maximum width close to caudal end, anterior part of cephalosome triangular shaped. Rostral spines as in female (Fig. 11C). Last thoracic somite without wings but with 2 spines on lateral margin, better developed on right side (Fig. 13A).

The urosome about half length of prosome (695:320
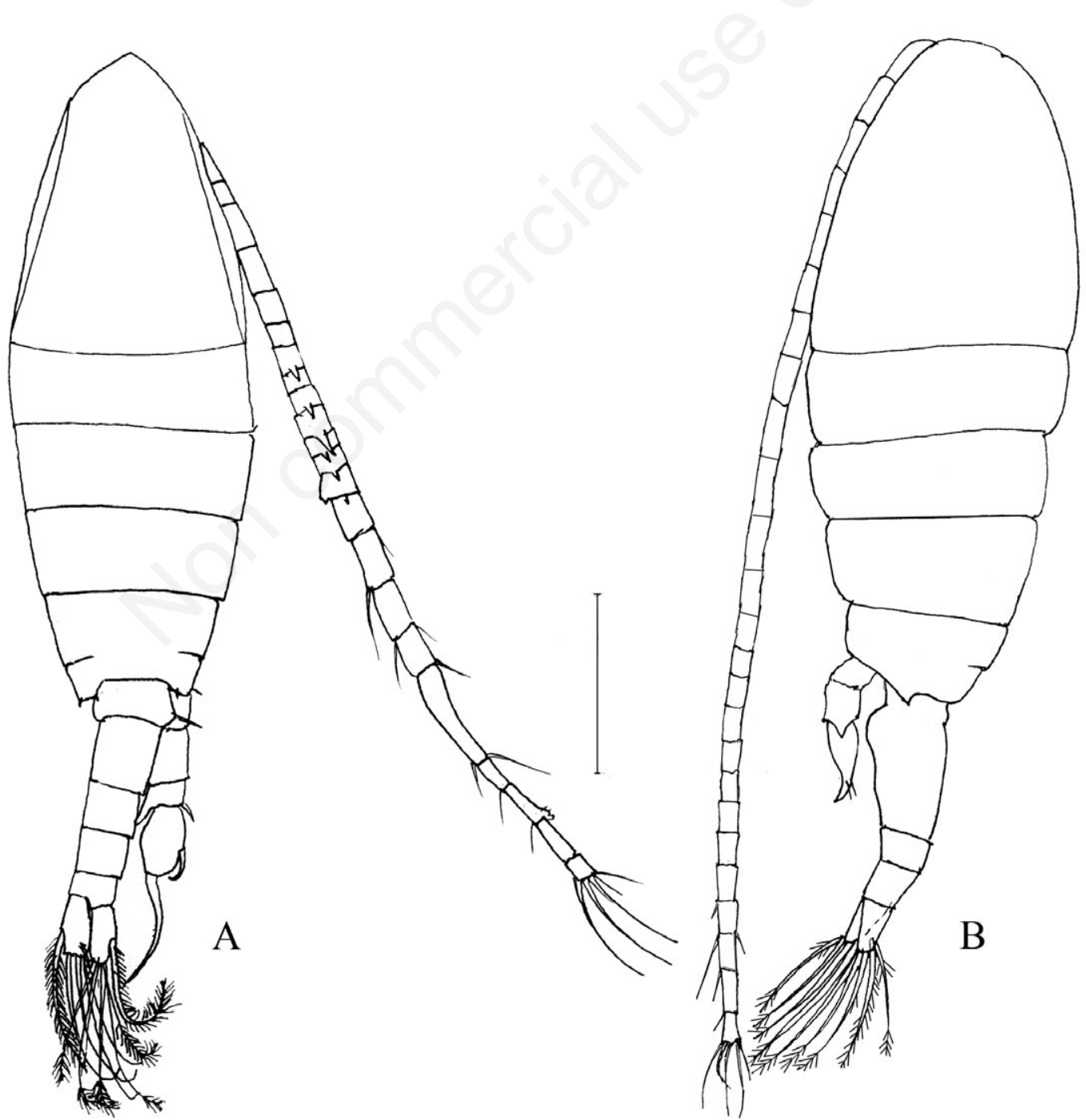

Fig. 10. Phyllodiaptomus praedictus sulawesensis n. ssp. male and female paratypes, lake Tondano, Sulawesi. A) Male; B) female. Scale bars $=200 \mu \mathrm{m}$. 

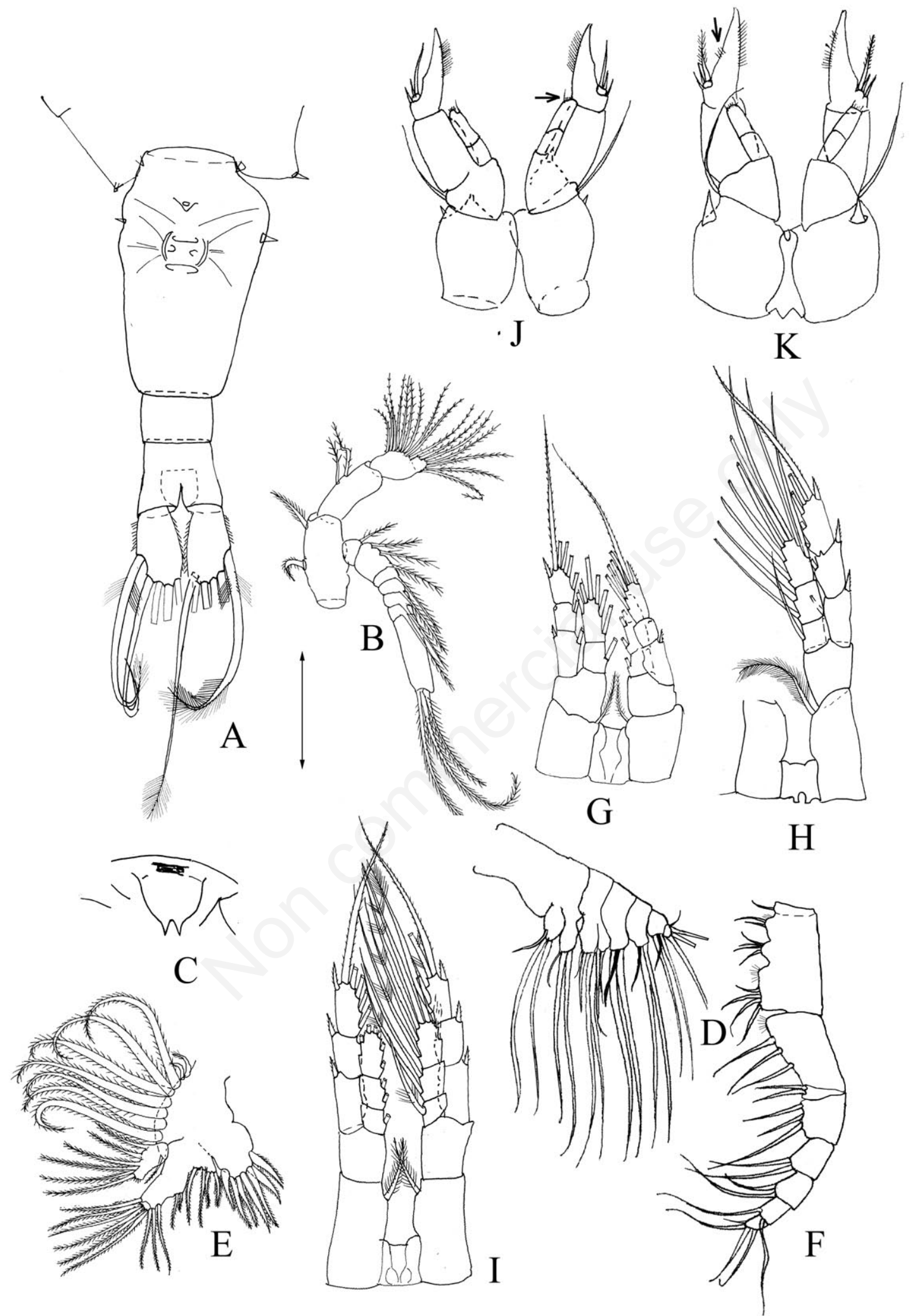

Fig. 11. Phyllodiaptomus praedictus sulawesensis n. ssp., lake Tondano, Sulawesi, female holotype. A) Urosome and last thoracic segment; B) antenna; C) rostrum; D) maxilla; E) maxillule; F) maxilliped; G,H) swimming legs 1-2; I) swimming leg 4; J,K) rudimentary leg 5 [arrows in $(\mathrm{J})$ indicate long spinules at distal end, while those in $(\mathrm{K})$ indicate hair-seta on outer side]. Scale bars of $\mathrm{A})=100 \mu \mathrm{m}$; $\mathrm{G}-\mathrm{I})=75 \mu \mathrm{m} ; \mathrm{B}-\mathrm{F}, \mathrm{J}-\mathrm{K})=50 \mu \mathrm{m}$. 
$\mu \mathrm{m}), 5$-segmented. The first urosomal segment clearly asymmetrical with long lateral spine on right side (Fig. 13A). Caudal rami symmetrical, 2 times as long as wide, with hair-like seta on inner margin. Terminal setae about 3 times as long as caudal rami.

Right antennule 22-segmented, $8^{\text {th }}$ and $10^{\text {th }}$ to $16^{\text {th }}$ segments with spines (Figs. 12D and 13F). Longest spine on $13^{\text {th }}$ segment, and twice as long as any other spine, just reaching end of next spine on segment $14^{\text {th }}, 15^{\text {th }}$ segment with short spine not reaching end of segment (Fig. 13F, arrowed). Antepenultimate segment produced into short comb-like serrated process with 2-3 large and 4-6 tiny teeth (Fig. 13 G, arrowed). Other segments with regular setae. Left antennule is 25 -segmented and armed as in female (Fig. 10A).

Antenna, mandible, maxillule, maxilla, and maxilliped (not shown) of same construction as in female.

Swimming legs P1-4 (not shown) constructed as in female.

Right leg 5 (Figs. 12A, 12B, 13B, and 13C): at distal inner corner coxa produced into triangular hyaline plate in intermediate shape between $P$. annae and P. sasikumari Reddy et Venkateswarlu, 1989. Coxal spine strong and conical in shape, similar to that in female (Fig. 13C). Elongated basipodal segment cylindrical in shape and with 2 small hyaline lobes on inner margin (Fig. 13B). Endopodite two-segmented, with relatively long spinules at subdorsal position (Fig. 12B), reaching to the middle of the second exopodal segment (Figs. 12B and 13B). First exopodal segment produced into long bent process at distal outer corner (Figs. 12B, 13B and 13C). Second segment wider in distal end, with long, bent distal spine twice as long as segment itself, end claw covered and armed with tiny spines on inner margin; lateral spine also bent, shorter than segment width (Fig. 13B and 13C).

Left leg 5 (Figs. 12B and 13B): coxal spine small, BAS also cylindrical but short, about as long as wide, with small seta inserted laterally. Exopodite 2-segmented, distal segment with apically serrated hyaline structure between strong apical process and modified seta (Fig. 12B). Endopodite two-segmented, group of short setules and long spine distally.

\section{Remarks}

The new subspecies appears to be very close to $P$. praedictus Reddy et Dumont, 1994, as these two forms are similar in many important morphological details of the genus. The most important difference between them lies in their ecological adaptations and preferences. Phyllodiaptomus praedictus that was described from Bangkok, Thailand inhabits small shallow ponds, rice fields and rivers (Dumont and Reddy, 1994), while P. praedictus sulawesensis n. ssp. successfully colonised large deep lakes. Beside this significant ecological difference there are also some small but clear morphological divergences among the males and females of $P$. praedictus praedictus and $P$. praedictus sulawesensis $\mathrm{n}$. ssp. In male of $P$. p. praedictus, the right antennule has a well-developed comb on the antepenultimate segment, typically with 4-7 large teeth more or less equal in size (Fig. 13E, arrowed); the spine on segment 13 is sharply bent over spine on segment 14 , segment 15 with a relatively long spine reaching end of the segment (Figs. 13D, arrowed). In male P. p. sulawesensis, the right antennule comb consists of 2-3 large and 4-5 tiny teeth (Fig. 13G, arrowed), the spine on segment 13 never bent over distal end of the spine on segment 14 (Fig. 13F, arrowed), segment 15 with a very short spine only reaching the middle of the distance between its insertion and the distal end of the segment (Fig. 13F, arrowed).

It is known that in males of some other species of the genus (e.g. Phyllodiaptomus blanci and P. wellekensae) the number of teeth and the size of the comb on the antepenultimate segment are subject to intra- and inter-population variation (Reddy, 1994). In our opinion, there are at least two reasons why these cannot be strong arguments for not using these characters for subspecies separation in our case. First, such variation observed in some species cannot be automatically presumed in other species. Second, we cannot exclude that large variation in these characters, supposedly important in the recognition of the conspecific mate, in fact masks taxonomical heterogeneity possibly existing in Phyllodiaptomus blanci and $P$. wellekensae. In the studied type population of P. p. praedictus, as much as we know the species from the original description, the variation in the number (4-7 large teeth) and the size of the comb do not match the corresponding character states in P. p. sulawesensis (2-3 large and 4-5 tiny teeth in 7 individuals studied).

It is important to note that these features belong mainly to sexual mate recognition characters: in the male it is the construction of the geniculate antennule, in the female it is the length of sensitive spinules on the distal segment of P5 ENP.

Phyllodiaptomus $p$. sulawesensis is also close to the type species of this genus P. blanci (de Guerne et Richard, 1896) widely distributed in Central and Southern Asia, as well as to P. annae (Apstein, 1907) and P. sasikumari Reddy et Venkateswarlu, 1989 that inhabit Southern India, Thailand and Sri Lanka. Phyllodiaptomus p. sulawesensis is separated from the other congeners by the presence of 12 long spinules at the distal end of ENP of P5 in both sexes.

Females of the new subspecies can also be discriminated by a combination of characters in P5 construction which includes: sensory basal setae long, extending beyond third exopodal segment (shorter in P. annae); inner outgrowth of second exopodal segment with dense hair-seta on inner side (on both sides in P. blanci and P. sasikumari); the third segment with long spine not reaching the end of 

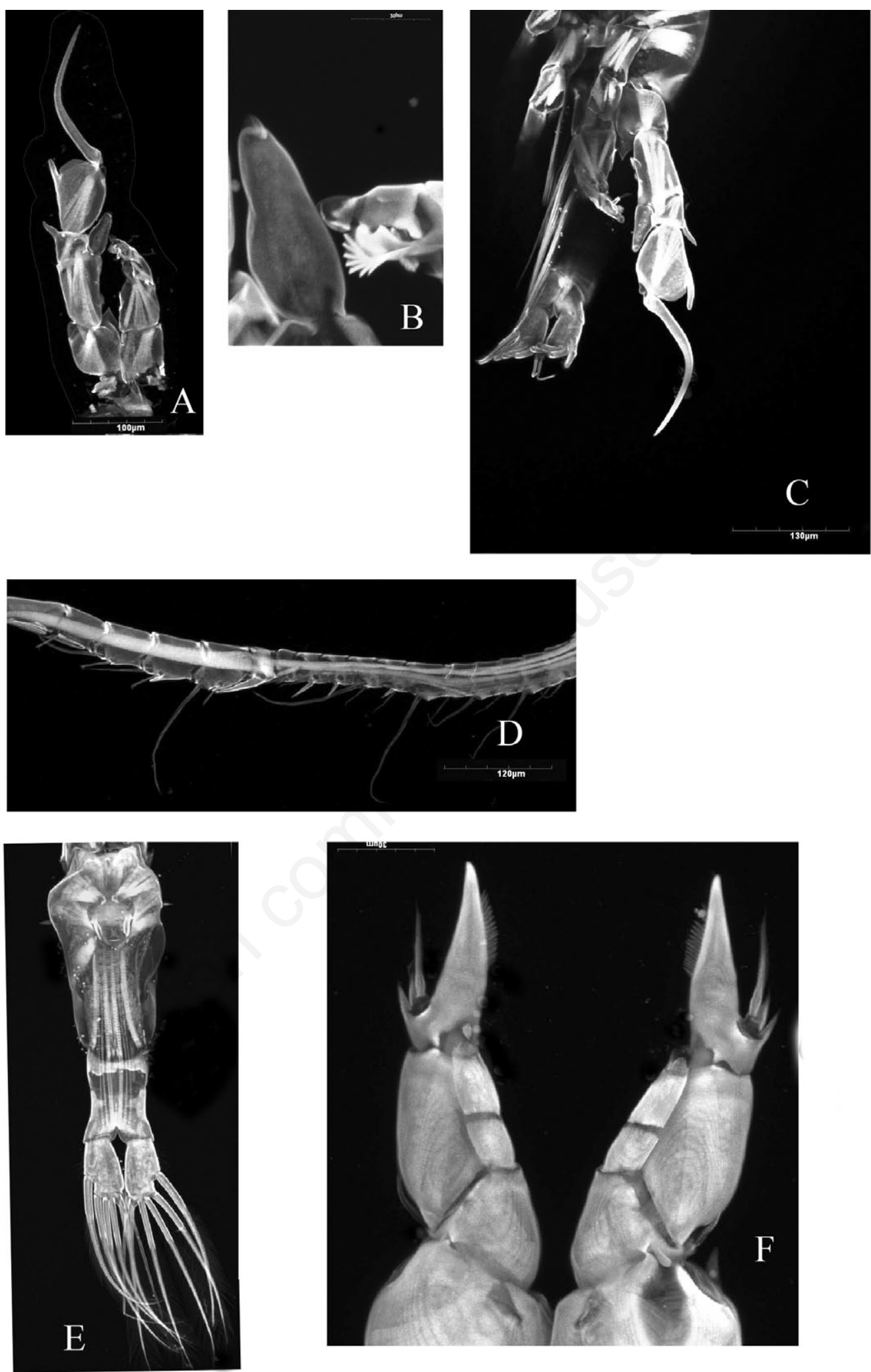

Fig. 12. Confocal laser scanning microscopy photographs of Phyllodiaptomus praedictus sulawesensis n. ssp., lake Tondano, Sulawesi, male and female paratypes. A) Male, rudimentary leg 5; B) male, endopodite of right leg 5 and distal exopodal segment of left leg 5; C) male, urosomal somites with leg 5; D) right antennule; E) female, urosomal somites, ventral; F) female, rudimentary leg 5. Scale bars of $A, E)=100 \mu \mathrm{m} ; B)=20 \mu \mathrm{m} ; C)=130 \mu \mathrm{m} ; \mathrm{D})=120 \mu \mathrm{m} ; \mathrm{F})=30 \mu \mathrm{m}$. 
inner outgrowth of second segment (extending well beyond the end of outgrowth in $P$. annae). Males of P. p. sulawesensis can additionally be distinguished from these three closely related species by the length of the spine on segment 13 of the antennule (shorter in P. annae, and longer in $P$. sasikumari), and by a long bent process on the first exopodal segment in the right leg 5 (absent in P. blanci, short in $P$. annae and straight in $P$. praedictus praedictus).

\section{Distribution}

This form was found in lake Tondano, Sulawesi only, and it likely is endemic to the lake and neighbouring water bodies.

The genus now includes 9 taxa mainly inhabiting Central and SE Asia (Borutzky et al., 1991; Reddy, 1994; Dussart and Defaye, 2002). Identification of P. praedictus sulawesensis n. ssp. from Sulawesi is the second finding of this genus outside of mainland Asia. The closest record of the genus was the description of $P$. longipes Kiefer, 1965 from West Kalimantan (Kiefer, 1965).

\section{DISCUSSION}

Copepod biodiversity in Indonesia has only been discussed for Calanoida (Lai and Fernando, 1980; Lai, 1986). Altogether, 11 species of diaptomids were reported from the four largest islands: 4 species from Sumatra (Tropodiaptomus australis Kiefer, 1936, T. vicinus Kiefer, 1930, T. hebereri Kiefer, 1930, T. doriai Richard, 1894), 2 species with 5 subspecies from Sulawesi (Neodiaptomus lymphatus, Eodiaptomus wolterecki wolterecki, E. w. matanensis, E. w. celebensis, E. w. tominangae), 6 species from Java [Mongolodiaptomus mephistopheles Brehm, 1933, M. uenoi ( Kikuchi, 1936), Neodiaptomus blachei (Brehm, 1951), Tropodiaptomus australis, Allodiaptomus raoi Kiefer, 1936, Dentodiaptomus javanus (Grochmalicki, 1915], and only one from Kalimantan (Tropodiaptomus vicinus) (Lai and Fernando, 1980).

Our survey increased the known calanoid biodiversity in this area about twice (Tab. 2). The largest taxa missing from previous investigations were the families Pseudodiaptomidae ( 3 species) and Acartiidae ( 2 species). Of the large islands of Indonesia, Java (10 species) appears to be the most species-rich, while Kalimantan (2 species) maintains the lowest biodiversity of calanoid species, which is consistent with previous studies.

The list of cyclopid species presented here includes more than 40 species, and to our knowledge it is the first summary of biodiversity in this group for this country. Java also has highest cyclopid biodiversity with 25 species of 12 genera (Tab. 1). Sumatra has 17 species, while Sulawesi with 5 species shows the poorest cyclopid biodiversity that certainly reflects low sampling intensity rather than real species richness.
Sulawesi takes a special place among other regions in Indonesia sheltering 8 species and 2 subspecies of calanoids only but showing the highest level of endemism (about $50 \%$ ). Sulawesi is recognised as a highly diverse land mass consisting of 3 biogeographical provinces resulting from its tectonic origin and the presence of several isolated ancient lakes (Brooks, 1950; Starobogatov, 1970). Most of the island's freshwater bodies belong to the Sulawesian province itself and in our samples this area was represented by lakes Laguna, Tolire, and Tondano. No endemic diaptomid species were found in the plankton of these first two small lakes. The copepod fauna was represented there by cyclopoids with global distributions ( $T$. crassus) or unclear origin (Mesocyclops sp.).

Lake Tondano, situated in the northern part of the island (Minahasa peninsula), contains an endemic diaptomid P. praedictus sulawesensis n. ssp. (DNA barcode: accession no. JN183939 - JN183940) closely related to a SE Asian group of species, the blanci-group, widely distributed in India, Bangladesh, and Malaysia. This species seems to represent the Asian element of Wallacea. Some specialists have proposed that this area of Sulawesi should be regarded as a separate biogeographical province because of its high number of Asiatic fauna elements compared to taxa with Australian ties (Brooks, 1950; Starobogatov, 1970). Phylogenetic analysis of this population shows two genetically differentiated lineages. It is possible that this species in lake Tondano is a hybrid form appeared from multiple colonisations of closely related but long time isolated populations (Vaillant et al., 2013).

The very local Posoan province is represented by the ancient lake Poso, the Poso river connecting this tectonic lake with the ocean, and several small lakes linked with the river (Starobogatov, 1970). Local endemic Neodiaptomus lymphatus (accession no. JN183941) and two populations of Thermocyclops crassus differing in size inhabit this ancient lake. Neodiaptomus lymphatus is evaluated as an endemic to Sulawesi, but having Asian origin as all other congeners that widely inhabit the lakes of this continent. The two populations of T. crassus found in lake Poso are differentiated by body size. Along with females of about $750 \mu \mathrm{m}$ in length that well fit individuals from the terra typica population (Peterhoff, Russia), we also found females of about $550 \mu \mathrm{m}$ in length. Although overlapping generations may be responsible for different size classes in plankton, the presence of adults in both groups suggests that they may be cryptic species. Differing size classes are known in copepods and may be a consequence of polyploidy or polyteny (McLaren et al., 1965).

The Malilian biogeographical province includes 3 large and 2 small lakes connected by several short rivers (Brooks, 1950; Starobogatov, 1970). Speciation in these lakes seems to be in progress as the largest and deepest lakes, Matano and Towuti, harbour two coexisting mor- 

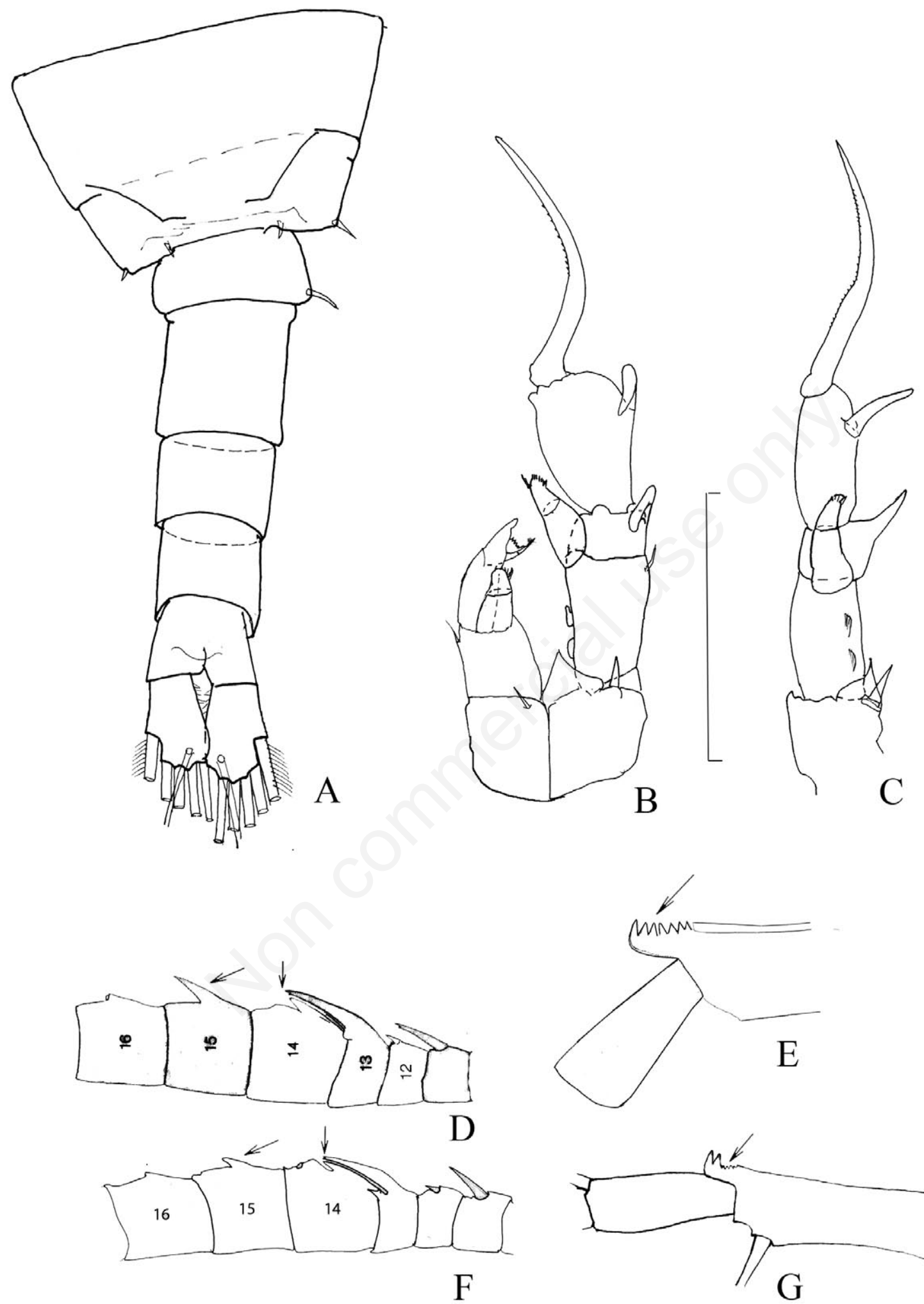

$\mathrm{F}$

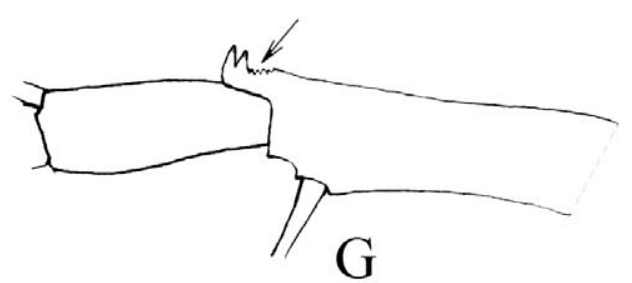

Fig. 13. Phyllodiaptomus praedictus sulawesensis n. ssp., lake Tondano, Sulawesi, male paratype (A-C,F,G) and P. praedictus praedictus Dumont et Reddy, 1994 male (D,E). A) Urosome and last thoracic somites; B) rudimentary leg 5, dorsal view; C) left leg 5, lateral view; D-F) male geniculate antennule, segments 11-16 (arrows indicate different length of spines on segments 14 and 15); E,G) combs on antepenultimate segment of male antennule (arrows indicate different number and size of denticles). Scale bars of A)=100 $\mu$ m; $\mathrm{B}, \mathrm{C})=75 \mu \mathrm{m} ; \mathrm{D}-\mathrm{F})=50 \mu \mathrm{m} ; \mathrm{E}, \mathrm{G})=40 \mu \mathrm{m}$. 
phologically and genetically differentiated species, $E$. wolterecki (accession no. JN183942) and E. matanensis (accession no. JN183943). The level of genetic divergence between $E$. wolterecki and $E$. matanensis, formerly considered as a subspecies of $E$. wolterecki, is striking (13\% sequence divergence) and warrants species status (Fig. 9). Such genetic differentiation over short geographic distance which copepods are able to readily disperse suggests an important role of natural selection in the divergence of these species. Strong natural selection on species in the Malili lakes is not unexpected, as it is implicated as a major driver of evolution in many other endemic species flocks inhabiting the lakes (Vaillant et al., 2011; von Rintelen et al., 2011). Indeed, lakes Matano and Towuti differ in many ecological and physical ways that may have a significant impact on diaptomid populations, including abundance of predatory fish, resource availability, and water mixing dynamics (Sabo et al., 2008; Haffner et al., 2001). Eodiaptomus wolterecki is also known from Cambodia and Philippines (Lai, 1986), while E. matanesis is endemic to the Malilian province (Dussart and Defaye, 2002). These forms also represent the SE Asian affinities of the Sulawesi diaptomids.

The endemic diaptomids of Sulawesi found during our survey so far have Asian origin and evolved due to the speciation processes, having colonised the ancient tectonic lakes isolated from one another for several million years. This isolation is considered to be 1-4 million years old (i.e. formed in the late Pliocene; Haffner et al., 2001). The presence of Eurasian and African elements in the zooplankton of Sulawesi lakes may be explained by more recent historical processes. Spanish and Portuguese galleons, followed by British and Dutch traders, first arrived here for tropical (colonial) goods. Since then, sailing ships became important vectors of human-mediated biological invasions, including freshwater fauna. Even though ships did not use freshwater as ballast until the end of $19^{\text {th }}$ century, aquatic organisms may have been transported with barrels for drinking water. Before reaching destination ports, ships regularly stopped ashore to collect new freshwater. Here, usually near river mouths, they washed barrels and re-filled them with new contents. This became one of the most prominent vectors of overseas transportation of zooplankton and may explain the presence of Eurasian T. crassus in both Sulawesi (lakes Poso and Selica) and Ternate (lake Tolire) islands. The population of this species from lake Tolire is close to the type population of $T$. crassus even in fine morphological details.

Mesocyclops aequatorialis similis, which is of African origin, can also be explained by overseas transportation. Before building the Suez canal in the $19^{\text {th }}$ century, the only way for European ships to reach SE Asia was to go around Africa. During this long trip, food and freshwater supplies were picked up from coastal sites many times. Similarly, some other African Mesocyclops species have been found in the Americas (Ueda and Reid, 2003). Molecular genetic studies are needed to confirm the invasive status of these two species and may be able to identify possible source regions from which they were transported by ancient ships.

Among the copepod species here found, Tropocyclops (Defayeicyclops) matanoensis Defaye, 2007 appears to have the most ancient origin. It may represent fauna of Pangean times, as another relative within this newly erected subgenus, Defayeicyclops, is found in Jamaica and belongs to another oceanic basin (Atlantic). Again, molecular systematics has the potential to corroborate this suggestion and may provide additional insights into the evolution of global copepod diversity.

High levels of endemism have already been evidenced by previous exploration of the phytoplankton, fish, decapods, and gastropods of Sulawesi (Haffner et al., 2001; von Rintelen et al., 2007; Bramburger et al., 2008; Schubart and Ng, 2008; von Rintelen and Cai, 2009). Our study confirms this endemism in the copepod fauna of the island. As plankton biotopes usually contain a small number of copepods that are primarily meiobenthic and littoral species, the total cyclopoid and harpacticoid fauna of Sulawesi has remained very poorly studied. This gap in knowledge must be closed in the near future as further limnological investigations are conducted to assess the status of the large lakes of Indonesia. Furthermore, this research will lay the groundwork for future ecological and evolutionary research in ancient lakes and other continental waterbodies and represents a strong basis for understanding the biodiversity and endemism of Indonesia.

\section{CONCLUSIONS}

Our list of the freshwater copepods of the Greater Sundas (Sumatra, Java, Borneo and Sulawesi) now includes 66 species, which certainly is an underestimation of the real species richness, as the fauna of Borneo and Sulawesi are still very poorly known.

In the few samples we had from Sumatra and Java, we found two new species, Eucyclops troposperatus Alekseev et Yusoff n. sp. (Sumatra) and Mesocyclops jakartensis Alekseev n. sp. (Java), which indicates that a more intensive sampling in these islands may reveal many more new taxa. On the other hand, in Sulawesi only few copepod species were encountered in the pelagic zone of the lakes, yet the copepod fauna of the littoral zone of the large ancient lakes and other habitat types have not been explored yet.

Human-mediated introduction of alien species can be a serious problem for the native freshwater fauna of the Indonesian islands. Two cyclopid species were supposedly introduced to Sulawesi: Mesocyclops aequatorialis similis Van de Velde, 1984 from Africa and Thermocy- 
clops crassus (Fischer, 1853) from Eurasia. To confirm this preliminary hypothesis, molecular-genetic tools (barcoding) should be applied.

We provided an updated key to the SE Asian species of the genus Eucyclops, as well as barcode information on several calanoid species from Sulawesi, which can facilitate future studies on the biodiversity of Indonesia.

\section{ACKNOWLEDGMENTS}

We would like to thank Melania Cristescu and members of the Cristescu's lab for providing valuable lab resources and feedback on the manuscript. We also thank Lili Nuria Lubis, Sinyo Rio, and Pak Dula for their assistance with field work. We are especially grateful to P.E. Hehanussa of the Indonesian Institute of Sciences (LIPI) and PT Vale Indonesia for facilitating our studies in Indonesia. Maria Miracle and Eduardo Vicente (Valencia University, Spain) provided us with very friendly access to confocal and scanning microscopes. We are thankful to Editors of this volume (especially Dr. Maria K. Hołyńska) for real help with the paper subscription and three anonymous referees for very productive criticism and discussion. This study was made possible through funding from the Natural Sciences and Engineering Research Council of Canada (NSERC), the Russian Academy of Sciences (RAS) grant on Biodiversity, and grant RFBR N11-04-00195-a.

\section{REFERENCES}

Alekseev V, Defaye D, 2011. Revision of Eucyclops serrulatus group (Copepoda, Cyclopoida, Eucyclopinae), p. 41-72. In: D. Defaye, E. Suárez-Morales and J.C. von Vaupel Klein (eds.), Studies on freshwater copepoda: a volume in honour of Bernard Dussart. Brill.

Borutzky JV, Stepanova LA, Kos MS, 1991. [Key for determination of freshwater Calanoidae of Russia]. [Book in Russian]. Nauka Publ., Leningrad: 504 pp.

Bramburger AJ, Hamilton PB, Hehanussa PE, Haffner GD, 2008. Processes regulating the community composition and relative abundance of taxa in the diatom communities of the Malili Lakes, Sulawesi Island, Indonesia. Hydrobiologia 615:215-224.

Brehm V, 1930. [Über südasiatischer Diaptomiden]. [Article in German]. Arch. Hydrobiol. 22:140-161

Brehm V, 1933. [Mitteilungen von der Wallacea-Expedition Woltereck. Mitteilung IV. Einige neue Diaptomiden]. [Article in German]. Zool. Anz. 103:295-304.

Brehm V, 1934. [Mitteilungen von der Wallacea-Expedition Woltereck. Mitteilung X. Über die systematische Stellung des von der Wallacea-Expedition entdeckten Pseudodiaptomus nostradamus Brehm und über die Systematik der Pseudodiaptomiden überhaupt]. [Article in German]. Zool. Anz. 106:84-93.

Brehm V, 1942. [Über dei Diaptomiden und Pseudodiaptomiden der Zwischeneregion Wallacea]. [Article in German]. Int. Rev. Ges. Hydrobio. 42:269-287.

Brehm V, Chappuis PA, 1935. [Mitteilungen von der Wallacea-
Expedition Woltereck. Mitteilung XI. Diaptomus s.1. (Heliodiaptomus?) Kieferi nov. spec. und Schizopera Tobae subsp. nov. Wolterecki]. [Article in German]. Zool. Anz. 111:237-240.

Brooks JL, 1950. Speciation in ancient lakes. Q. Rev. Biol. 25:30-60.

Carl J, 1907. [Copépodes d'Amboine]. [Article in French]. Rev. Suisse Zool. 15:7-18.

DeAngelis MM, Wang DG, Hawkins TL, 1995. Solid-phase reversible immobilization for the isolation of PCR products. Nucleic Acids Res. 23:4742-4743.

Defaye D, 2007. A new Tropocyclops (Copepoda, Cyclopoidae) from Lake Matano, Indonesia. Zootaxa 1541:17-29.

Dumont HJ, Reddy YR, 1994. Phyllodiaptomus praedictus n. sp. (copepoda, Calanoida) from Thailand. Hydrobiologia 273:101-110.

Dussart B, Defaye D, 2002. World directory of the Crustacea Copepoda of inland waters. I. Calaniformes. Backhuys, Leiden: $285 \mathrm{pp}$.

Dussart BH, Fernando CH, 1988. [Sur quelques Mesocyclops (Crustacea, Copepoda)]. [Article in French]. Hydrobiologia 127:241-264.

Dussart BH, Sarnita AS, 1987. A new freshwater copepod, Mesocyclops brevisetosus sp.nov. (Crustacea, Copeoda) from Kalimantan, Indonesia. Can. J. Zool. 65:2731-2733.

Fernando CH, Alekseev VR, 1999. Freshwater zooplankton and literature at the National University of Singapore (NUS). SILnews 27:8.

Folmer O, Black M, Hoeh W, Lutz R, Vrijenhoek R, 1994. DNA primers for amplification of mitochondrial cytochrome $\mathrm{C}$ oxidase subunit I from diverse metazoan invertebrates. Mol. Mar. Biol. Biotech. 3:294-299.

Franke U, 1989. [Katalog zur Sammlung limnischer Copepoden von Prof. Dr. Friedrich Kiefer. 5. Carolinea]. [Book in German]. Landessammlungen für Naturkunde Karlsruhe, Karlsruhe: $433 \mathrm{pp}$.

Green J, Sorbet SA, Watts E, Oey Biau Lan, 1976. Ecological studies on Indonesian lakes. J. Zool. 180:315-354.

Grochmalicki J, 1915. [Beitrag zur Kenntnis der süsswassefauna Javas. Phyllopoda, Copepoda und Ostracoda]. [Article in German]. Ext. Bull. Acad. Sci. Cravovie 1915:217-242.

Haffner GD, Hehanussa PE, Hartoto D, 2001. The biology and physical processes of large lakes of Indonesia, p. 183-194. In: M. Munawar and R.E. Hecky (eds.), The great lakes of the world: food-web health and integrity. Backhuys.

Heberer G, Kiefer F, 1932. [Zur Kenntnis der Copepodenfauna der Sunda-Inseln]. [Article in German]. Arch. Naturgesch. 1:225-274.

Hołyńska M, 2000. Revision of the Austrolasian species of the genus Mesocyclops (Copepoda, Cyclopidae). Ann. Zool. 50:363-447.

Hołyńska M, 2006a. On species of the genus Thermocyclops (Copepoda: Cyclopidae) occurring in Northern Queensland, Australia. Ann. Zool. 56:335-364.

Hołyńska M, 2006b. Phylogeny of Mesocyclops (Copepoda:Cyclopoidae) inferred from morphological characters. Zool. J. Linn. Soc.-Lond. 147:1-70.

Hołyńska M, Reid JW, Ueda H, 2003. Genus Mesocyclops Sars, 1914, p. 13-213. In: H. Ueda, and J.W. Reid (eds.), Copepoda: Cyclopoida. Genera Mesocyclops and Thermocyclops. 
Guides to the identification of the microinvertebrates of the continental waters of the world. Backhuys.

Huys R, Boxshall GA, 1991. Copepod evolution. The Ray Society ed., London: 468 pp.

Karaytug S, 1999. Copepoda: Cyclopoida. Genera Paracyclops, Ochridacyclops and key to the Eucyclopinae. Guides to the identification of the microinvertebrates of the continental waters of the world. Backhuys, Leiden: $217 \mathrm{pp}$.

Kiefer F, 1927. [Versuch eines Systems der Cyclopiden Beiträge zur Copepodenkunde]. [Article in German]. Zool. Anz. 73:302-308.

Kiefer F, 1928. [Beiträge zur Copepodenkunde (VII). Zur Nomenklatur zweier Halicyclops. 16. Über Systematik der Oithona- und Cyclopina-Änlichen]. [Article in German]. Zool. Anz. 75:216-223.

Kiefer F, 1929. [Neue Ruderfusskrebse von den Sunda-Inseln. 1. Mitteilung über die Copepoden der Sunda Expedition Reusch-Heberer]. [Article in German]. Zool. Anz. 84: 46-49.

Kiefer F, 1930a. [Neue Cyclopiden von den Sunda-Inseln. 2. Mitteilung über die Cyclopiden der Deutschen Limnologischen Sunda-Expedition]. [Article in German]. Zool. Anz. 90:55-58.

Kiefer F, 1930b. [Neue Cyclopiden von den Sunda-Inseln. 2. Mitteilung über die Copepoden der Sunda-Expedition Rensch]. [Article in German]. Zool. Anz. 86:185-189.

Kiefer F, 1931. [Kurze Diagnosen neuer Süsswassercopepoden]. [Article in German]. Zool. Anz. 94:219-224.

Kiefer F, 1933. [Die freilebende Copepoden der Binnengewasser von Insulinde]. [Article in German]. Arch. Hydrobiol. 12:519-621.

Kiefer F, 1938. [Beiträge zur Copepodenkunde (XIX)]. [Article in German]. Zool. Anz. 123:274-280.

Kiefer F, 1939. [Bemerkungen zur Pseudodiaptomidenausbeute der Wallacea-Expedition]. [Article in German]. Int. Rev. Ges. Hydrobio. 38:75-98.

Kiefer F, 1952. [Copepoda Calanoida und Cyclopoida. Exploratie vall het Nationaal Albert Park Zending H. Damas (1935-1936)]. [Book in German]. Iinstituut der Nationale Parken du Congo Belge Van Belgisch Congo ed., Brussels: 136 pp. Available from: http://www.apncb.be/archives/publications/exploration-national-park-albert/exploration-national-park-albert-first-series/mission-h-damas-1935-1936/1 952-fascicule-21-copepoda-calanoida-und-cyclopoida/ fascicule-21-tot.pdf/download

Kiefer F, 1965. [Beitrage zur Copepodenkunde. Eine neue Art der Gattung Phyllodiaptomus]. [Article in German]. Zool. Anz. 175:460-465.

Kiefer F, 1982. [Tropodiaptomus vandouwei (Früchtl, 1924) ein vergessener Diaptomide aus Indonesien (Crustacea, Copepoda)]. [Article in German]. Senckenb. Biol. 62:393-397.

Lai HC, 1986. The freshwater Calanoida (Crustacea, Copepoda) of Indonesia. Indo-Malayan Zool. 3:39-61.

Lai HC, Fernado CH, 1980. Zoogeographical distribution of Southeast Asian freshwater Calanoida. Hydrobiologia 74:53-66.

Lindberg K, 1955. [Contribution à l'étude de la faune d'eau douce de Corse. Copepodes]. [Article in French]. Vie Milieu 6:241-247.

McLaren IA, Woods SM, Shea JRJr, 1965. Polyteny: a source of cryptic speciation among copepods. Science 153:16411642.

Menzel R, 1926. [Cyclopoides muscicoles et bromélicoles de Java]. [Article in French]. Ann. Biol. Lac. 14:209-216.

Moniez R, 1892. [Entomostracés d'eau de Sumatra et de Celebes. II Ostracodes] [Chapter in French], p. 129-135. In: M. Weber (ed.), [Zoologische Ergebnisse einer Reise in Niederlandisch Ost-Indien, 2]. [Book in German]. Brill.

Reddy YR, 1994. Copepoda: Calanoida: Diaptomidae. Guides to the identification of the microinvertebrates of the continental waters of the world. SPB Acad. Publ., The Hague: $221 \mathrm{pp}$.

Reid JW, Janetzky W, 1996. Colonization of Jamaican bromeliads by Tropocyclops jamaicensis n. sp. (Crustacea: Copepoda: Cyclopoida). Invertebr. Biol. 115:305-320.

Richard J. 1894. [Entomostacés recueillis par M.E. Modigliani dans le lac Toba (Sumatra)]. [Article in French]. Ann. Mus. Civ. Stor. Nat. Genova. 2:565-578.

Sabo E, Roy D, Hamilton PB, Hehanussa PE, McNeely R, Haffner GD, 2008. The plankton community of Lake Matano: factors regulating plankton composition and relative abundance in an ancient, tropical lake of Indonesia. Hydrobiologia 615:225-235.

Sarasin P, Sarasin F, 1898. [Die Süsswasser Mollusken von Celebes. Materialen zur Naturgeschichte der Insel Celebes]. [Article in German]. C.W. Kredel's Verl., Weisbaden: 104 pp.

Schubart CD, Ng PKL, 2008. A new molluscivore crab from Lake Poso confirms multiple colonization of ancient lakes in Sulawesi by freshwater crabs (Decapoda: Brachyura). Biol. J. Linn. Soc. 154:211-221.

Schwenk K, Sand A, Boersma M, Brehm M, Mader E, Offerhaus D, Spaak P, 1998. Genetic markers, genealogies and biogeographic patterns in the Cladocera. Aquat. Ecol. 32:3751.

Starobogatov JI, 1970. [Fauna of mollusk and zoogeographical regions among continental waterbodies of the globe]. [Book in Russian]. Nauka Publ., Leningrad: 372 pp.

Steuer A, 1923. [Revision der Gattung Acartia Dana]. [Article in German]. Zool. Anz. 45:392-397.

Stingelin T, 1900. [Beiträg zur Kenntnis der Süsswasserfauna von Celebes. Enotomostraca]. [Article in German]. Rev. Suisse Zool. 193-207.

Tamura K, Dudley J, Nei M, Kumar S, 2007. MEGA4: molecular evolutionary genetics analysis (MEGA) software version 4.0. Mol. Biol. Evol. 24:1596-1599.

Ueda H, Reid JW, 2003. Copepoda: Cyclopoida. Genera Mesocyclops and Thermocyclops. Guides to the identification of the microinvertebrates of the continental waters of the world. Backhuys, Leiden: $221 \mathrm{pp}$.

Vaillant JJ, Bock DG, Haffner GD, Cristescu ME, 2013. Speciation patterns and processes in the zooplankton of the ancient lakes of Sulawesi Island, Indonesia. Ecol. Evol. 3:3083-3094.

Vaillant JJ, Haffner GD, Cristescu ME, 2011. The ancient lakes of Indonesia: towards integrated research on speciation. Integr. Comp. Biol. 51:634-643.

Van de Velde I, 1984. Revision of the African species of the genus Mesocyclops Sars, 1914 (Copepoda, Cyclopoida). Hydrobiologia 109:3-66. 
Van de Velde I, 1987. New Mesocyclops species (Copepoda, Cyclopoida) from Papua New Guinea. Bull Inst. R. Sc. N. B.S. 57:149-163.

von Rintelen K, Cai Y, 2009. Radiation of endemic species flocks in ancient lakes: systematic revision of the freshwater shrimp Cardina H. Milne Edwards, 1837 (Crustacea: Decapoda: Atyidae) from the ancient lakes of Sulawesi, Indonesia, with the description of eight new species. Raffles B. Zool. 57:343-452.

von Rintelen T, Bouchet P, Glaubrecht M, 2007. Ancient lakes as hotspots of diversity: a morphological review of an endemic species flock of Tylomelania (Gastropoda:
Cerithioidea: Pachychilidae) in the Malili lake system on Sulawesi, Indonesia. Hydrobiologia 592:11-94.

von Rintelen T, von Rintelen K, Glaubrecht M, Schubart C, Herder F, 2011. Aquatic biodiversity hotspots in Wallacea: the species flocks in the ancient lakes of Sulawesi, Indonesia, p. 290-315. In: D.J. Gower, K.G. Johnson, J.E. Richardson, B.R. Rosen, L. Rüber and S.T. Williams (eds.), Biotic evolution and environmental change in Southeast Asia. Cambridge University Press.

Whitten T, Henderson GS, Mustafa M, 2002. The ecology of Sulawesi. The ecology of Indonesia. Periplus ed., Hong Kong: 754 pp. 